\title{
INDICAÇÃO DE PROGRAMAS PARA A SECAGEM CONVENCIONAL DE MADEIRAS
}

\section{ARIEL DE ANDRADE}

Engenheiro Florestal

Orientador: Prof. Dr. IVALDO PONTES JANKOWSKY

\begin{abstract}
Dissertação apresentada à Escola Superior de Agricultura "Luiz de Queiroz", Universidade de São Paulo, para obtenção do título de Mestre em Ciências, Área de Concentração: Ciência e Tecnologia de Madeiras.
\end{abstract}

P I R A C I C A B A

Estado de São Paulo - Brasil

Fevereiro - 2000 


\title{
Dados Internacionais de Catalogação na Publicação (CIP) DIVISÃO DE BIBLIOTECA E DOCUMENTAÇÃO - Campus "Luiz de Queiroz"/USP
}

\author{
Andrade, Ariel de \\ Indicaçāo de programas para a secagem convencional de madeiras / Ariel de \\ Andrade. - Piracicaba, 2000. \\ 72 p. : il. \\ Dissertação (mestrado) - - Escola Superior de Agricultura Luiz de Queiroz, 2000. \\ Bibliografia. \\ 1. Economia florestal 2. Espécie florestal 3. Madeira 4. Propriedade fisico-química \\ 5. Secagem da madeira 6. Tecnologia de madeira I. Título
}

CDD 674.38 


\section{ERRATA}

\begin{tabular}{|c|c|c|}
\hline Pág. / Parágrafo / Linha & Onde se lê... & Leia-se... \\
\hline $19 / \mathrm{Tab} .1 / 6$ & $\mathrm{Ts}=40($ quando umid $=40 \%)$ & $\mathrm{Ts}=45$ \\
\hline $25 / \mathrm{Tab} .2 / 1$ & Tabela 2. Relação de espécies. & $\begin{array}{l}\text { Tabela 2. Relação de espécies e } \\
\text { gêneros. }\end{array}$ \\
\hline $26 / 1 / 1$ & $\begin{array}{l}\text { A identificação das espécies foi } \\
\text { realizada... }\end{array}$ & $\begin{array}{l}\text { A identificação das espécies e } \\
\text { gêneros foi realizada... }\end{array}$ \\
\hline $26 / 3 / 1$ & $\begin{array}{l}\text { Os parâmetros dos programas } \\
\text { foram... }\end{array}$ & $\begin{array}{l}\text { Os parâmetros dos programas } \\
\text { (temperatura inicial, final e } \\
\text { potencial de secagem) foram... }\end{array}$ \\
\hline $26 / 4 / 2$ & ...preferencialmente bem úmidas... & $\begin{array}{l}\text {..o mais saturadas possível (com } \\
\text { umidade acima do PSF)... }\end{array}$ \\
\hline $34 / 1 / 1$ & $\begin{array}{l}\text {..Eucalipto grandis, Jatobá, Pau- } \\
\text { Marfim... }\end{array}$ & $\begin{array}{l}\text {..Eucalipto grandis, Jatobá, } \\
\text { Mandioqueira, Pau-Marfím... }\end{array}$ \\
\hline $36 /$ Tab. $7 / 3$ & $V 3=0,186$ (Eucalipto grandis) & $V 3=0,0091$ \\
\hline $36 /$ Tab. $7 / 8$ & $U \mathrm{U}=52,6$ e me $e_{b}=78$ (Jatobá) & $U_{i}=48,6 e^{-m_{b}}=0,87$ \\
\hline $36 / \mathrm{Tab} .7 / 9$ & $\mathrm{Ui}=48,6$ e $\mathrm{me}_{\mathrm{b}}=0,87$ (Jutai-Cica) & $\mathrm{Ui}_{\mathrm{i}}=52,6 \mathrm{e} \mathrm{me}_{\mathrm{b}}=, 78$ \\
\hline $36 /$ Tab. $7 / 15$ & $V 3=0,0096$ (Tauari) & $\mathrm{V} 3=0,0125$ \\
\hline $38 / 3 / 1$ & $\begin{array}{l}\text {...verifica-se claramente que as } \\
\text { madeiras... }\end{array}$ & $\begin{array}{l}\text {...verifica-se claramente (Tabela } 28 \\
\ldots \text { Apêndice 2) que as madeiras...; }\end{array}$ \\
\hline $39 / 3 / 5$ & ...Esta metodologia permite indicar... & $\begin{array}{l}\text {... Esta metodologia, conforme } \\
\text { Brandão (1989), permite indicar.. }\end{array}$ \\
\hline $53 / 1 / 17$ & ...é indicado efetuar. & ...é recomendável efetuar... \\
\hline $67 /$ Tab. 27/11 & $\mathrm{Ui}_{\mathrm{i}}=35,38$ (Pau-Marfim) & $\mathrm{Ui}=57,78$ \\
\hline
\end{tabular}

\begin{tabular}{|c|c|}
\hline Localização & Incluir \\
\hline Pág. 32, após último parágrafo & $\begin{array}{l}\text { A umidade final desejada das espécies submetidas à secagem } \\
\text { convencional é de } 12 \% \text {. }\end{array}$ \\
\hline Pág. 34, após o $1^{\circ}$ parágrafo & $\begin{array}{l}\text { As espécies poderão ser grupadas em um mesmo programa de } \\
\text { secagem em funçấo da similaridade de valores dos parâmetros } \\
\text { temperatura inici al,final e potenci al de secaem. }\end{array}$ \\
\hline Pág. 40, após Tabela 9 & $\begin{array}{l}\text { A metodologia recomenda os rogramas para peças com até } 28 \mathrm{~mm} \\
\text { de espessura, entretanto, devido a necessidade de enviar informações às } \\
\text { empresas fornecedoras de material e para avaliar o comportamento de } \\
\text { peças mais espessas, as madeiras de Freijo e Imbuia foram submetidas } \\
\text { aos programas indicados, apesar de apresentarem espessuras maiores. }\end{array}$ \\
\hline $\begin{array}{l}\text { Pág. } 53 \text {, entre as duas primeiras } \\
\text { conclusóes }\end{array}$ & $\begin{array}{l}\text { - os resultados da secagem convencional foram satisfatórios para as } \\
\text { madeiras de Freijo, Jutai-Cica e Perøa-Mica. A madeira de lmbuia, } \\
\text { com alta incidência defeitos e desuniformidade de umidade, não } \\
\text { apresentou resultados satisfatórios; }\end{array}$ \\
\hline
\end{tabular}


À memória de meu pai

(Octávio Augusto Fricks de Andrade)

DEDICO 


\section{AGRADECIMENTOS}

- Aos pais, pelo apoio e incentivo ao longo do trabalho;

- Ao Prof. Ivaldo Pontes Jankowsky, pela orientação e amizade;

- Aos professores do curso de Ciência e Tecnologia de Madeiras, pelos conhecimentos transmitidos;

- À CAPES, pela concessão da bolsa de mestrado;

- Aos técnicos do IPT, que auxiliaram na identificação das madeiras estudadas;

- Às empresas Indusparquet Ind. Com. de Madeiras Ltda, Florestas Rio Doce S.A., Móveis Rizzon Ltda e ao Sr. Cleimar Basso, pelo fornecimento de parte das madeiras estudadas;

- Ao técnico de laboratório Pedro dos Santos Souza, pela grande ajuda na parte prática;

- Aos Pesquisadores do Laboratório de Produtos Florestais (LPF/IBAMA), Varlone Alves Martins e Márcia Helena B. Marques, pelas sugestões apresentadas;

- Aos Engenheiros Florestais, Cláudio Del Menezzi, Deisiane Lúcio, Gianpaola Ciniglio, Inês Galina e Marcos Ducatti, pelas contribuições e discussões;

- Às pessoas que de alguma maneira contribuiram para realização deste trabalho;

- Aos amigos de Brasília e Piracicaba, pela amizade e convivência. 


\section{SUMÁRIO}

Página

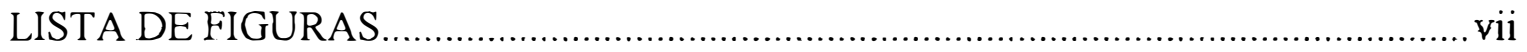

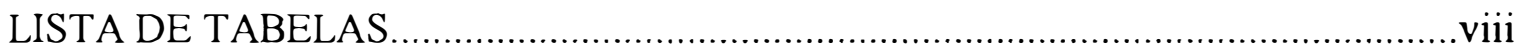

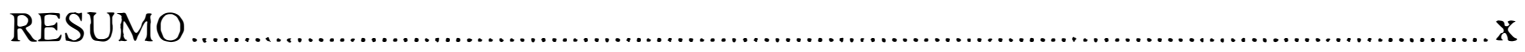

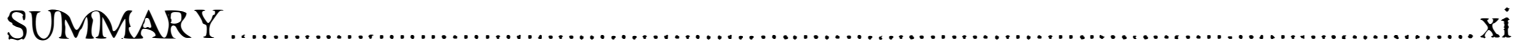

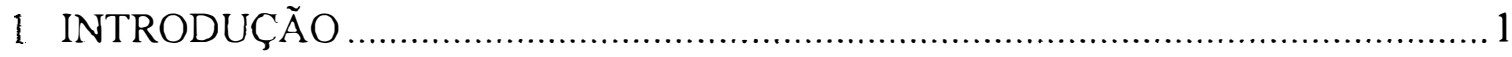

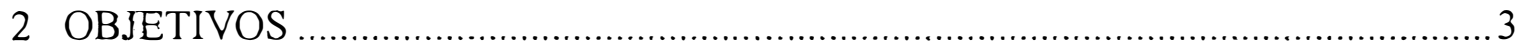

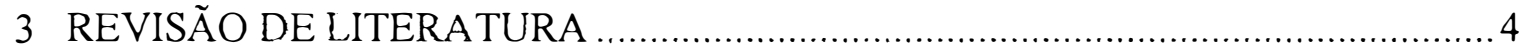

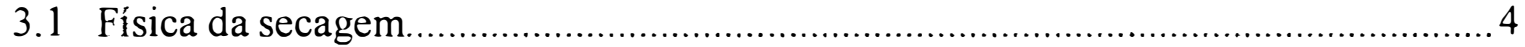

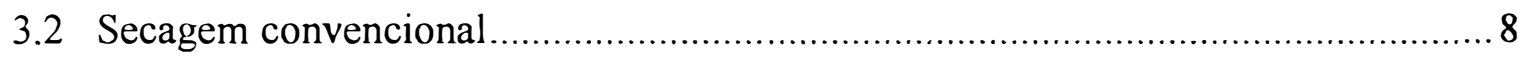

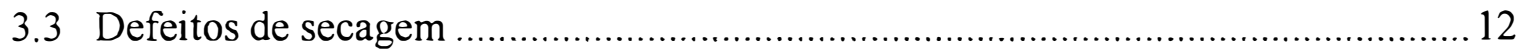

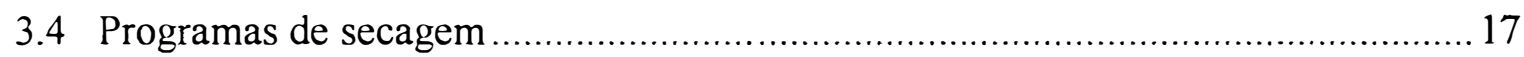

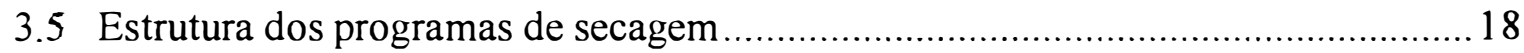

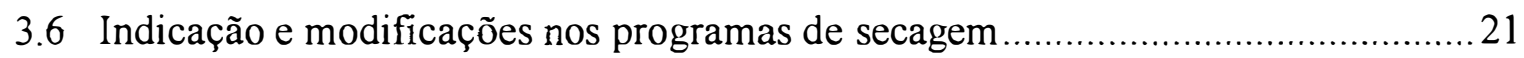

3.7 Grupamento de madeiras para secagem convencional ..........................................2

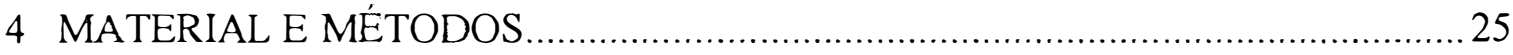

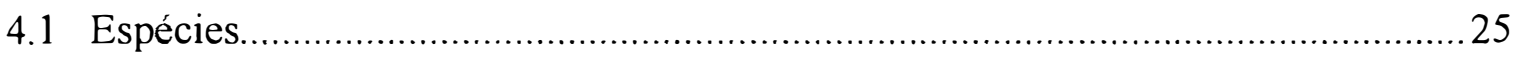

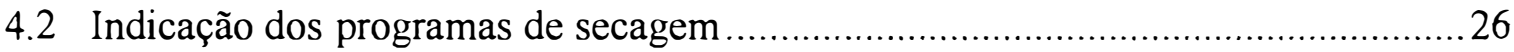

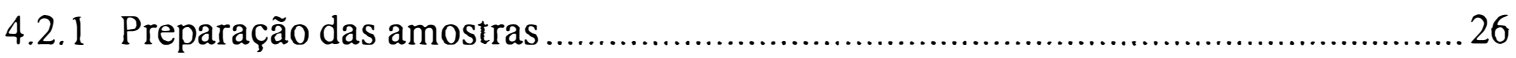

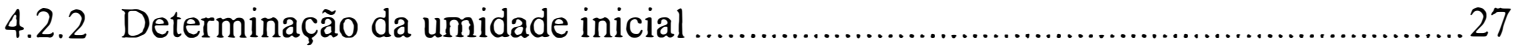

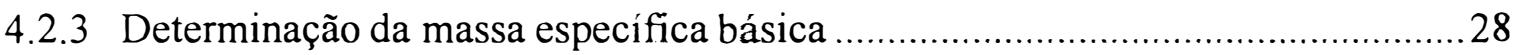

4.2.4 Ensaio para determinação dos programas de secagem ......................................28

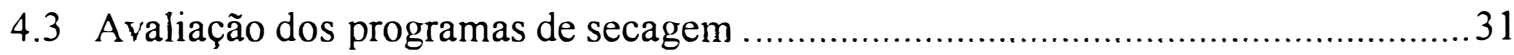

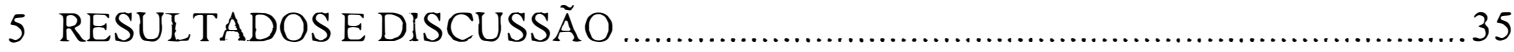

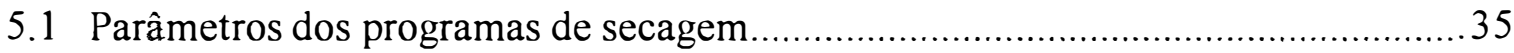

5.2 Secagem convencional das madeiras de Freijó, Imbuia, Jutaí-Cica e Peroba-Mica 
5.3 Programas de secagem para Jatobá, Mandioqueira, Pau-Marfim,

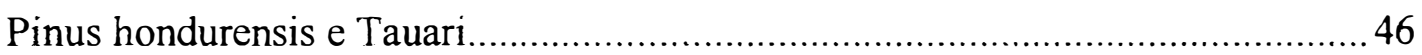

5.4 Programas de secagem para Eucalipto tereticornis, Itaúba e Tamboril...................48

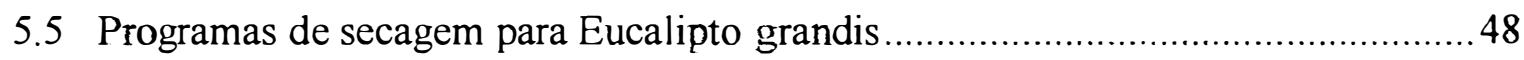

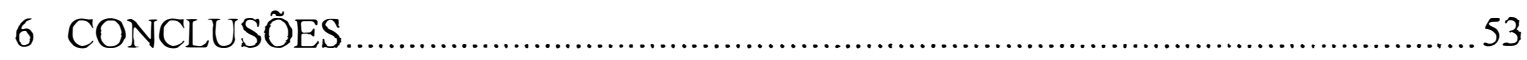

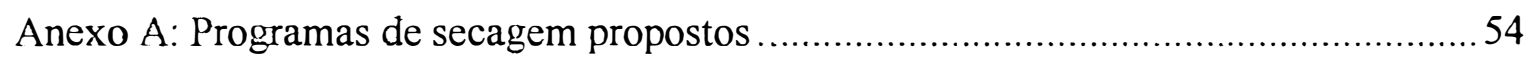

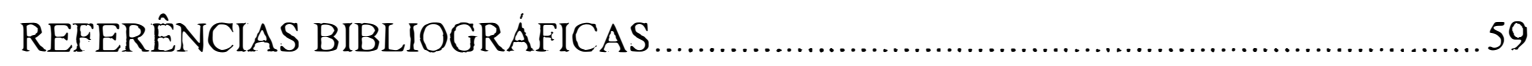

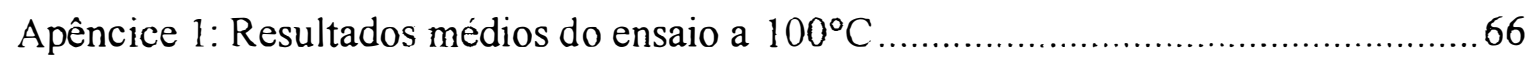

Apêndice 2: Amplidude de variação dos resultados obtidos no ensaio a $100^{\circ} \mathrm{C}$..............68

Apêndice 3: Programas seguidos nos ensaios de secagem convencional........................70 


\section{LISTA DE FIGURAS}

Página

1 Possíveis formas de movimentação da água higroscópica.................................... 8

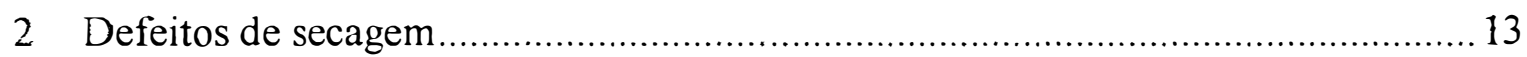

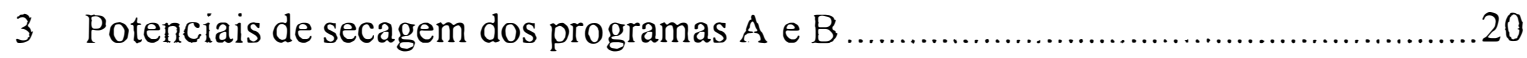

4 Esquema de retirada dos corpos de prova ................................................. 27

5 Retirada dos corpos de prova para os testes de qualidade ................................. 33

6 Classificação das tensões de secagem........................................................ 33

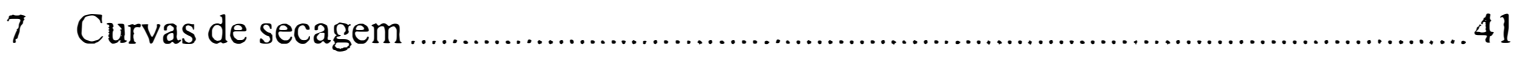




\section{LISTA DE TABELAS}

Página

1 Programas de secagem para madeira de Jatobá com até $38 \mathrm{~mm}$ de espessura......... 19

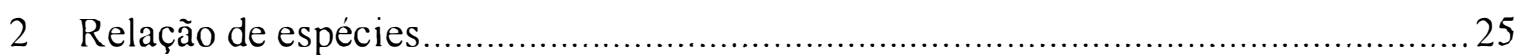

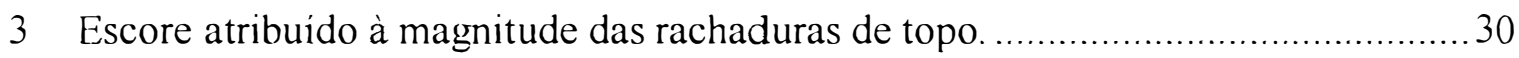

4 Equações para determinação dos parâmetros do programa de secagem.....................30

5 Classifícação da tendència ao aparecimento de defeitos ......................................... 31

6 Classificação das rachaduras após secagem convencional ....................................32

7 Valores médios do teor de umidade inicial, da massa específica básica e das

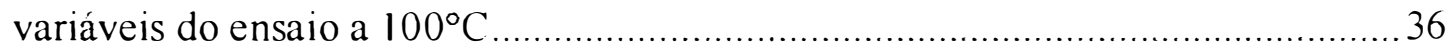

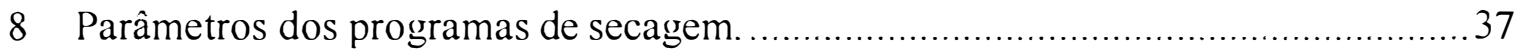

9 Características das madeiras submetidas à secagem convencional ........................40

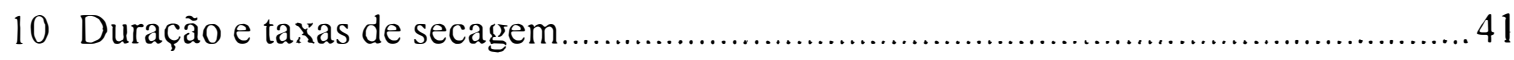

11 Velocidades de secagem no ensaio a $100^{\circ} \mathrm{C}$ e na secagem convencional ...............42

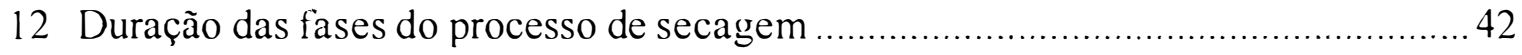

13 Porcentagem de peças que apresentaram defeitos. ................................................ 43

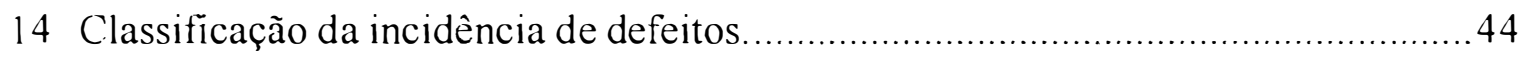

15 Distribuição da umidade final (média e amplitude de variação) ……………............4 44

16 Comparação dos programas de secagem com informações disponiveis em

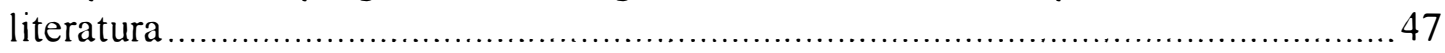

17 Condições de secagem convencional do Eucalipto grandis ....................................49

18 Porcentagem de peças de Eucalipto grandis que apresentaram defeitos antes e após a secagem convencional 
19 Programas de secagem para Eucalipto grandis 51

20 Programa de secagem proposto para as madeiras de Eucalipto tereticornis, Freijó, Jatobá e Jutai-Cica com até $28 \mathrm{~mm}$ de espessura 55

21 Programa de secagem proposto para as madeiras de Eucalipto grandis, Pau-Marfim, Tamboril e Tauari com até $28 \mathrm{~mm}$ de espessura.

22 Programa de secagem proposto para madeira de Imbuia com até $28 \mathrm{~mm}$ de espessura 56

23 Programa de secagem proposto para a madeira de Peroba-Mica com até $28 \mathrm{~mm}$ de espessura 56

24 Programa de secagem proposto para a madeira de Mandioqueira com até $28 \mathrm{~mm}$ de espessura

25 Programa de secagem proposto para a madeira de Itaúba com até $28 \mathrm{~mm}$ de espessura

26 Programa de secagem proposto para a madeira de Pinus hondurensis com até $28 \mathrm{~mm}$ de espessura

27 Valores médios do teor de umidade inicial, da massa especifica básica e das variáveis do ensaio a $100^{\circ} \mathrm{C}$

28 Amplitude de variação (máximo e minimo) dos resultados obtidos no ensaio a $100^{\circ} \mathrm{C}$

29 Programa de secagem empregado para a madeira de Freijó

30 Programa de secagem empregado para a madeira de Imbuia 71

31 Programa de secagem empregado para a madeira de Jutai-Cica 72

32 Programa de secagem empregado para a madeira de Peroba-Mica. 72 


\title{
INDICAÇÃO DE PROGRAMAS PARA A SECAGEM CONVENCIONAL DE MADEIRAS
}

\author{
Autor: ARIEL DE ANDRADE \\ Orientador: Prof. IVALDO PONTES JANKOWSKY
}

\section{RESUMO}

Atualmente o nível de perdas de madeira ligado ao processo de secagem alcança valores significativos. Um dos fatores que contribui para essa situação é a carência de programas de secagem apropriados para as diversas espécies de madeiras. $\mathrm{O}$ objetivo principal do trabalho foi indicar programas de secagem para madeiras de diferentes espécies florestais e analisar a possibilidade de grupamento visando a secagem convencional. Para elaboração dos programas foi aplicada a metodologia de secagem drástica a $100^{\circ} \mathrm{C}$, que correlaciona a intensidade de defeitos, tempo e velocidade de secagem com o possível comportamento na secagem convencional. As análises para verificação da validade dos programas foram realizadas através de experimentação e por comparações com a literatura especializada. Os resultados obtidos para os parâmetros dos programas de secagem (temperatura inicial, temperatura final e potencial de secagem) foram coerentes e seguros, possibilitando a indicação dos programas de secagem específicos para as madeiras de Imbuia (Ocotea porosa), Itaúba (Mezilaurus itauba), Mandioqueira (Qualea sp.), Peroba-Mica (Aspidosperma sp.) e Pinus hondurensis (Pinus caribaea var. hondurensis); e grupar as madeiras de Eucalipto grandis (Eucalyptus grandis), Eucalipto tereticornis (Eucalyptus tereticornis), Freijó (Cordia goeldiana), Jatobá (Hymenaea sp.), Jutai-Cica (Martiodendron sp.), PauMarfim (Balfourodendron riedelianum), Tamboril (Enterolobium contortisiliquum) e Tauari (Couratari sp.) em 2 programas básicos. 


\title{
SUGGESTION OF KILN SCHEDULES TO CONVENTIONAL DRYING OF LUMBER
}

\author{
Author: ARIEL DE ANDRADE \\ Adviser: Prof. IVALDO PONTES JANKOWSKY
}

\section{SUMMARY}

Lumber losses due to wrong practices of conventional drying can reach significant values at wood products industry. One factor, which contributes to this situation, is the lack of adequate kiln schedules to several lumber species. The objective of this study research was to indicate kiln schedules for lumber of different wood species and to study the possibility of grouping some of those species in the same basic kiln schedule. Kiln suggestion was based on the $100^{\circ} \mathrm{C}$ screening. This methodology correlates the drying rate and defects intensity at $100^{\circ} \mathrm{C}$ to the expected behavior during conventional kiln drying. The results (suggested kiln schedules) were analyzed through the application of kiln schedules to dry some species using a laboratory kiln and comparing the schedules to available data in literature. Obtained results for the kiln schedules parameters (initial temperature, final temperature and drying potential) were coherent, and it was possible to indicate specific kiln schedules to Imbuia (Ocotea porosa), Itaúba (Mezilaurus itauba), Mandioqueira (Qualea sp.), Peroba-Mica (Aspidosperma sp.) and Pinus hondurensis (Pinus caribaea var. hondurensis) lumbers, and to group Eucalipto grandis (Eucalyptus grandis), Eucalipto tereticornis (Eucalyptus tereticornis), Freijó (Cordia goeldiana), Jatobá (Hymenaea sp.), Jutai-Cica (Martiodendron sp.), Pau-Marfim (Balfourodendron riedelianum), Tamboril (Enterolobium contortisiliquum) e Tauari (Couratari sp.) lumbers in 2 basic kiln schedules. 


\section{INTRODUÇÃO}

A madeira sempre ocupou lugar de destaque dentre os diversos materiais usados pelo homem. Atualmente, com o desenvolvimento técnico e científico, busca-se cada vez mais conhecer e aprimorar os diversos processos que envolvem a industrialização da madeira, visando melhorar sua utilização e aproveitamento.

A secagem é uma fase de grande importância nos processos de transformação da madeira em produtos, pois proporciona, entre outras vantagens, melhoria das características de trabalhabilidade e redução tanto da movimentação dimensional como da possibilidade de ataque de fungos e insetos. Além disso, quando o processo é realizado em secadores e conduzido de maneira adequada, obtém-se considerável redução do tempo de secagem e maior controle sobre os defeitos.

Entretanto, o processo de secagem artificial nas indústrias brasileiras é considerado uma fase extremamente crítica, pois trata-se de uma operação que requer considerável investimento prévio e representa parcela significativa do custo operacional. Além disso, o nível de perdas de madeira, gerado pela falta de informações sobre as espécies e secagens mal conduzidas, também é elevado. De acordo com Ducatti ${ }^{1}$, a quantidade de peças defeituosas ou tensionadas, após o processo, pode ser de até $100 \%$ do material seco. Um dos fatores que contribui para esta situação é a carência de programas de secagem apropriados para as madeiras usadas na indústria.

Cada espécie ou tipo de madeira apresenta comportamento próprio durante o processo de secagem; entretanto, existem espécies com características similares e que poderiam ser grupadas em um mesmo programa de secagem.

'DUCATTI, M.A. (Comunicação Pessoal, 1997). 
O grupamento de espécies deve ser considerado como alternativa pelas indústrias, pois o fornecimento de matéria-prima. principalmente da floresta tropical, está ficando comprometido devido às crescentes dificuldades para a exploração das reservas existentes. Para as empresas, essa possibilidade apresenta vantagens como redução do estoque. pois deixa de ser necessário manter estoques elevados para carregar o secador com material homogêneo. além de favorecer a utilização de um número maior de espécies. incluindo as não tradicionais ou de baixa freqüência na floresta.

Verifica-se a necessidade da indicação segura de programas de secagem, incluindo a possibilidade de grupamento. para espécies conhecidas e, principalmente. não tradicionais: contribuindo assim com informações que proporcionem melhor aproveitamento dos recursos florestais. 


\section{OBJETIVOS}

\subsection{Objetivo Geral}

O presente trabalho tem como objetivo principal indicar programas de secagem para madeira de diferentes espécies florestais e analisar a possibilidade de grupamento visando a secagem convencional.

\subsection{Objetivos Específicos}

- verificar a validade da metodologia para indicação de programas de secagem;

- avaliar o comportamento das madeiras submetidas à secagem convencional;

- fornecer informações técnicas sobre as madeiras estudadas em relação ao processo de secagem convencional. 


\section{REVISÃO DE LITERATURA}

A secagem da madeira é o processo da redução da sua umidade. com o objetivo de atingir um teor de umidade pré-determinado. com o mínimo de defeitos, no menor tempo possível e de uma forma economicamente viável para o uso a que se destina (Martins. 1988).

\subsection{Física da Secagem}

Do ponto de vista físico, a secagem de madeiras pode ser definida como um balanço dinâmico entre a transferência de calor da corrente de ar para a madeira, a evaporação superficial na madeira. difusão de umidade através da madeira e o fluxo de massa da água capilar (Hart. 1965).

O calor é transferido do meio secante (ar) para a superfície da madeira por convecção. Após a superfície ser aquecida. este calor é transferido para o interior por condução. No início da secagem. quando a madeira está úmida, a transferência de calor do ambiente para a superfície é o fator mais importante. A medida que a madeira perde umidade, a transferência de calor da superficie para o interior passa a ser o fator limitante. É por esta razão que altas velocidades de ar são mais importantes na primeira fase de secagem do que no final.

A transferência de calor e a evaporação superficial são controladas pelas condições externas e o movimento de umidade do interior até a superfície da madeira é controlada principalmente por propriedades da madeira como a permeabilidade e a massa específica (Galvão \& Jankowsky, 1985). 
Em relação à movimentação de água no interior da madeira devem ser considerados tanto a difusão como o fluxo capilar. De acordo com diversos autores como Brow et al. (1949), Kollmann \& Côté (1968), Siau (1971) e Skaar (1988), existem diferentes formas de água na madeira, das quais as principais são:

- capilar; água no estado líquido, contida nos espaços intra e inter-celulares, principalmente no lume dos vasos, das fibras, traqueides e outros elementos anatômicos;

- higroscópica; água adsorvida na superfície e no interior da parede celular, ligada aos componentes básicos da madeira principalmente por pontes de hidrogênio (atração entre moléculas).

Segundo Baker (1956), a água na madeira se movimenta de zonas de alta umidade para zonas de baixa umidade, significando que a parte externa da madeira deve estar mais seca do que seu interior, para que haja secagem. Os elementos situados na superficie cedem água para o ar que a envolve, tanto mais rapidamente quanto mais alta for a temperatura, menor a umidade relativa e maior a velocidade de deslocamento desse ar. Após a diminuição da umidade da superfície, ocorre movimentação da umidade do interior para a parte externa.

Deste modo, começa a se formar um gradiente de umidade que, segundo Perelygin (1965), reflete-se nas diferentes umidades de uma peça de madeira ao longo de suas dimensões (largura, espessura e comprimento). Esta irregularidade na distribuição da umidade é mais acentuada em tábuas grossas, necessitando-se de mais tempo para sua uniformização.

De acordo com Baker (1956), Siau (1984), Skaar (1988) e outros autores, quando a madeira está secando, várias forças agem simultaneamente na movimentação da umidade, destacando-se os fenômenos físicos da capilaridade e da difusão.

A capilaridade atua na movimentação da água no estado liquido, através de capilares representados na madeira principalmente pelos lumes e pontoações. A tensão capilar, que causa a movimentação do líquido, é decorrente da tensão superfícial 
na interface gás / líquido e inversamente proporcional ao raio do capilar. Essa relação é expressa, na equação 1, pela Lei de Jurin (Lepage et al., 1986).

$\Delta \mathrm{P}=\frac{2 \bullet \gamma \bullet \cos \Theta}{\mathrm{r}} \quad$ onde:

$\Delta \mathrm{P}=$ diferencial de pressão (tensão capilar);

$\gamma=$ tensão superficial do líquido;

$\theta=$ ângulo de umidecimento;

$\mathrm{r}=$ raio do capilar.

A facilidade de escoamento da água líquida na madeira define a sua permeabilidade, propriedade física que resulta principalmente da sua estrutura anatômica. Considerando que o fluxo de líquidos através do material madeira obedece as Leis de Darcy e de Poiseuille, Jankowsky (1986) demonstra que a permeabilidade está relacionada com o raio do capilar, conforme a equação 2 .

$\mathrm{k}=\frac{\mathrm{N} \cdot \pi \cdot \mathrm{r}^{4}}{8 \cdot \mu \cdot \mathrm{A}} \quad$ onde

$\mathrm{k}=$ permeabilidade;

$\mathrm{N}=$ número de capilares;

$r=$ raio dos capilares;

$\mu=$ viscosidade do líquido;

$\mathrm{A}$ = área da amostra, perpendicular à direção do fluxo.

O movimento da água higroscópica pode ser considerado como um fenômeno de difusão (Galvão \& Jankowsky, 1985); a qual é definida por Bennett \& Myers (1978) como o transporte de massa resultante do movimento casual das moléculas e da diferença de concentração. De acordo com Oliveira (1981), as moléculas de água se movimentam de regiões com elevadas concentrações para regiões com baixas 
concentrações. Assim como a velocidade de difusão da água higroscópica depende do gradiente de umidade, a difusão do vapor d'água é função do gradiente de pressão. No interior da madeira, a pressão de vapor aumenta de acordo com a elevação da umidade até o Ponto de Saturação das Fibras (PSF). Acima do PSF, dificilmente será possível observar de maneira significativa a movimentação de água no estado de vapor.

Ponce \& Watai (1985) salientam que o movimento de vapor d'água através de espaços vazios na madeira depende da umidade relativa do ar confinado nestes espaços e do ar que envolve a madeira. Caso este ar possua uma baixa umidade relativa, o vapor d'água irá se mover da madeira úmida para a atmosfera. Assim, a velocidade de secagem depende da umidade relativa do ar (externo) que envolve a madeira, da umidade na superfície da madeira e da diferença de umidade desenvolvida entre a superfície e o interior da peça.

Durante a secagem é possível dizer que os mecanismos de movimentação por difusão de vapor d'água e de água higroscópica sejam realizados simultaneamente (Oliveira, 1981). A difusão da água higroscópica ocorre até o instante em que a molécula de água atinge a cavidade celular. Quando isto acontece, a água, em estado de vapor, começa a se movimentar por difusão através do ar contido no lume. Durante o seu percurso para a superficie da madeira, a água no estado de vapor é novamente adsorvida por uma outra parede celular, para então ocorrer outra vez o mecanismo de difusão da água higroscópica. Esta combinação de mecanismos, ilustrada na Figura 1, será repetida até que a molécula de água atinja a superfície da madeira. 

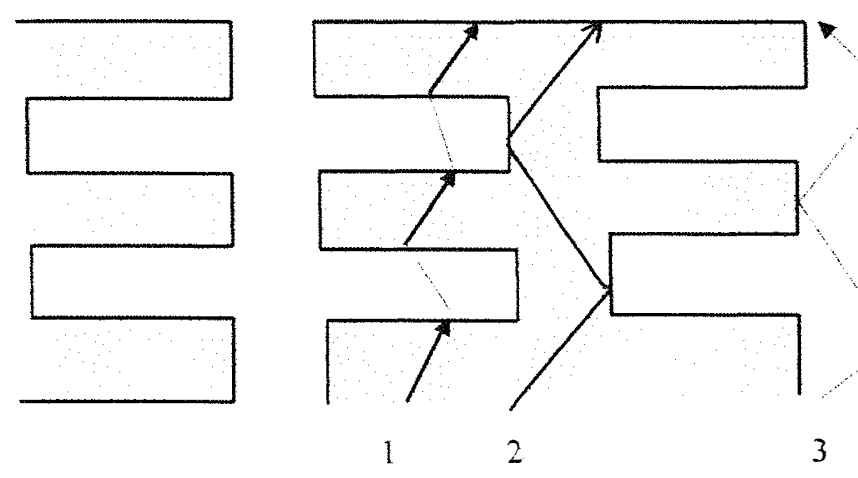

1- Combinação: difusão de água higroscópica e vapor d'água

2- Difusão de água higroscópica

3- Difusão de vapor d'água

Figura 1 - Possíveis formas de movimentação da água higroscópica na madeira (Oliveira, 1981).

\subsection{Secagem convencional}

A secagem convencional é aquela conduzida em estufas ou secadores, onde se tem total controle da circulação do ar, da temperatura e da umidade relativa. Segundo STCP (1.990), este é o processo de maior aplicação na indústria madeireira.

De acordo Pratt (1974), os secadores convencionais podem ser definidos como câmaras de secagem que operam com temperaturas entre $35^{\circ}$ e $90^{\circ} \mathrm{C}$. Esses equipamentos dispõem de um sistema de aquecimento; um sistema de umidificação do ar; um conjunto de "dampers" ou janelas que permitem a troca de ar entre o interior do secador e o meio externo; e um sistema de ventilação que promove a circulação do ar através das pilhas de madeira.

Os secadores convencionais são os mais utilizados principalmente para a secagem da madeira de folhosas. O sistema de aquecimento mais comum é uma bateria de trocadores de calor que pode utilizar como fluído térmico o ar quente, água quente, vapor d'água ou óleo térmico. A umidificação do ar é obtida pela liberação de vapor de baixa pressão ou com a aspersão de água fria dentro do secador. A circulação do ar é promovida por um conjunto de ventiladores, posicionados lateralmente em relação a 
madeira ou sobre o falso teto acima das pilhas. Os "dampers" ou janelas são colocados de tal forma que a ação dos ventiladores faz com que o ar quente e úmido do interior do secador seja expelido, admitindo ar do meio externo (Jankowsky, 1995).

A secagem convencional, segundo Tuset \& Duran (1986), apresenta como principais vantagens, em relação à secagem ao ar livre, a independência das condições climáticas, menor duração, maior controle sobre os defeitos e umidade final, adequação a todo tipo de madeira e ampla experimentação disponivel. Entretanto, é considerado um processo inadequado para secar peças espessas.

As principais restrições da secagem convencional estão ligadas ao investimento inicial e à necessidade de mão-de-obra especializada. Os investimentos não são somente aqueles diretamente relacionados à compra do secador, pois um setor de secagem convencional necessita ainda de caldeiras, instalações hidráulicas, elétricas, rede de vapor, barracões e outras obras, que em seu conjunto acabam sendo elevadas (STCP, 1990).

O processo de secagem convencional sofre influências do material madeira, das variáveis do processo em si, ou seja, temperatura, umidade relativa e velocidade do ar, e também da prévia preparação da madeira.

Em relação ao material, as madeiras mais densas e as peças com maior espessura, requerem mais tempo para secar. De acordo com Martins (1988), a massa especifica está muito relacionada com a permeabilidade, que é um dos fatores que mais influenciam na secagem. Contudo, esta afîrmativa é discutivel.

Maior massa específica significa maior espessura da parede celular e menor volume do lume. Dessa forma, madeiras mais densas possuem maior quantidade de água higroscópica, cuja movimentação é mais lenta.

Por outro lado, menor massa especifica implica em maior quantidade de água no estado líquido, cuja movimentação depende principalmente do raio dos capilares, através dos quais verifica-se o escoamento do fluido, conforme mostra a equação 2. Devido à estrutura do material madeira, os capilares de menor raio serão as pontoações que interligam os lumes dos diversos elementos anatômicos. 
Assim, a permeabilidade é uma propriedade extremamente variável dentro de uma mesma peça de madeira (Jankowsky, 1986; Cavalcante, 1991), não se conhecendo uma relação direta com a massa específica.

A espessura das peças também influencia no processo, porque 0 incremento na espessura implica também no aumento da proporção entre a massa de água a ser retirada e a superfície de evaporação, tornando o processo mais lento. De acordo com Tomaselli (1980), a velocidade de secagem é inversamente proporcional a espessura das tábuas. Além disso, Rasmussem (1961) frisa que as tábuas mais espessas tendem a apresentar mais defeitos.

A grã e a textura são características que também influenciam no processo. De acordo com Rasmussem (1961) e Burguer \& Richter (1990), espécies com grã regular e textura grossa apresentam maior facilidade de secagem. Os extrativos também interferem no processo, pois aumentam a massa específica e obstruem os canais, dificultando a secagem.

A direção estrutural também afeta a movimentação de água. De acordo com IPT (1985), as tábuas de corte tangencial secam mais rapidamente do que as tábuas de corte radial, pois a posição dos raios em relação à espessura das peças favorece a retirada de umidade do interior da madeira. Entretanto, esta movimentação mais rápida pode favorecer a ocorrència de defeitos.

Tanto o fluxo da água capilar como a difusão da água higroscópica são maiores no sentido longitudinal do que no transversal, e maiores na direção radial em comparação com a tangencial (Siau, 1984).

Em relação às variáveis do processo, a elevação da temperatura contribuirá para o aumento de velocidade de remoção da água, tanto para os mecanismos de difusão, quanto para a movimentação de água capilar (Oliveira, 1981). Entretanto temperaturas muito elevadas podem causar maior degradação no material. 
Yamamoto $^{2}$, citado por Brandão (1989), salienta que temperaturas muito elevadas proporcionam evaporação da umidade superficial muito mais rápida do que a movimentação de umidade no interior da madeira, tornando o processo ineficaz.

De acordo com Hildebrand (1970), durante a retirada da água capilar, temperaturas muito elevadas não precisam ser utilizadas, pois o efeito do aquecimento não aumenta significativamente a velocidade de secagem. Por outro lado, o aumento da temperatura tem influência no processo de difusão, afetando a retirada da água higroscópica.

Se a temperatura está relacionada com o fornecimento de energia para a evaporação da água, a umidade relativa está relacionada com a capacidade do ar em receber maior ou menor quantidade de vapor d'água e com a remoção da água da superficie da madeira. Assim, quanto menor a umidade relativa do ar, maior a quantidade de água que o ar pode conter (Galvão \& Jankowsky, 1985).

Adicionalmente, a circulação do ar é também um fator de grande importância no processo. Sua finalidade é transferir calor do sistema de aquecimento para o secador, distribuir o calor uniformemente na câmara, misturar e condicionar o ar antes de sua passagem pela carga e remover a umidade da superfície da madeira.

Vários autores recomendam o uso de maiores velocidades do ar no caso de madeiras com umidades iniciais elevadas. Tomaselli (1980) salienta que um aumento na velocidade do ar implica em um aumento na velocidade de secagem e, normalmente, um aumento na temperatura deve ser acompanhado de um aumento na velocidade do ar.

Além das características do material e das variáveis do processo, a preparação da carga para entrada na estufa também é outro aspecto de extrema importância no desempenho da secagem e na qualidade das peças ao final do processo (Ponce \& Watai, 1985).

Hildebrand (1970) e Galvão \& Jankowsky (1985) frisam que, para reduzir o período de secagem e minimizar os defeitos, a recomendação geral é secar uma

\footnotetext{
${ }^{2}$ YAMAMOTO, A. K. Secagem das Madeiras. Boletim Técnico, ABPM. São Paulo, 2 (1), 1974.
} 
espécie por vez e com peças, preferencialmente, de mesma espessura e qualidade. Além disso, a madeira da carga deve ter aproximadamente a mesma umidade no início da secagem.

Ponce \& Watai (1985) destacam que a seleção e o uso adequado dos tabiques ou separadores reduzem sensivelmente os empenamentos das tábuas, favorecendo que a secagem transcorra de maneira mais rápida e uniforme. Os tabiques devem ser confeccionados de madeiras com alta resistência. sem defeitos e grã reta; feitos a partir de tábuas secas em estufa. Suas dimensões devem ser de acordo com a largura da pilha. tipo e dimensões das tábuas a serem secas. O posicionamento, espaçamento e o alinhamento dos tabiques também são importantes durante o processo de secagem. Para redução dos empenamentos das tábuas durante a secagem, as filleiras de tabiques devem ser alinhadas verticalmente.

\subsection{Defeitos de secagem}

Os defeitos que ocorrem na madeira durante a secagem causam significativos preịuízos para quem seca madeira e desestimula a utilização de determinadas espécies susceptíveis a esses defeitos: contribuindo para a exploração seletiva, responsável pelo reduzido número de espécies atualmente comercializadas (Martins.1988).

Brandão (1989) define como defeito de secagem toda e qualquer alteração que venha a ocorrer na estrutura da madeira que dificulte seu reprocessamento, em uma fase posterior.

Os principais defeitos gerados durante o processo de secagem são os empenos, as rachaduras, o colapso e o endurecimento superficial (Figura 2). 


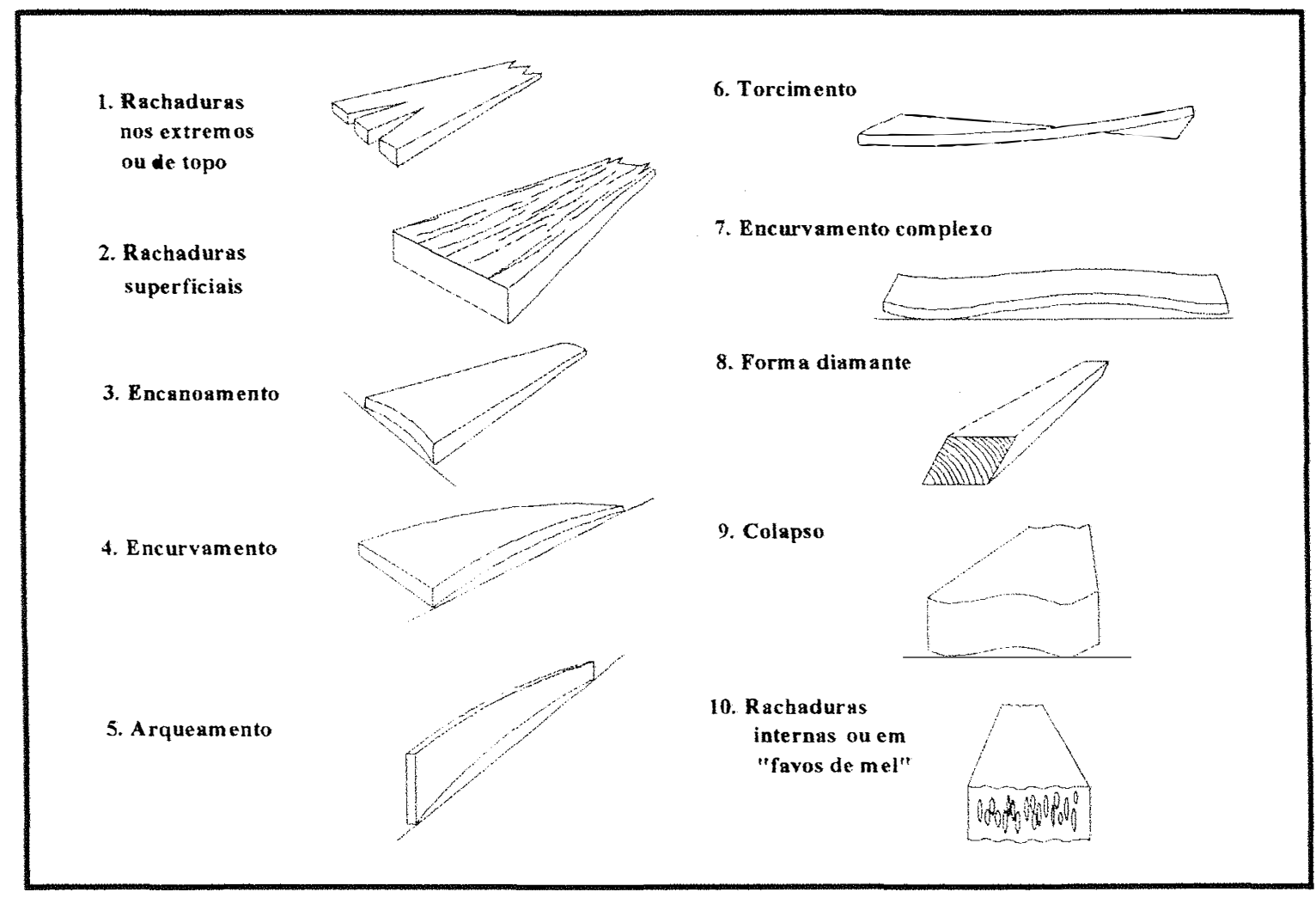

Figura 2 - Defeitos de secagem (Mendes et al.,1998).

De acordo com Oliveira (1981), o empenamento pode ser entendido como qualquer distorção ocorrida na madeira em relação ao seu plano original. Os diversos tipos de empenamentos podem ser ocasionados por diferenças das contrações existentes entre os anéis de crescimento, lenho juvenil e adulto, cerne e alburno, desvios na orientação das fibras e presença de madeira de reação. Rasmussen (1961), Pratt (1974), Galvão e Jankowsky (1985), Martins (1988), dentre outros, citam que existem cinco formas comuns de empenos:

- encanoamento, que é gerado quando ocorre secagem mais rápida de uma face ou quando uma face se contrai mais que a outra, mesmo com secagem uniforme, devido ao plano em que foi feito o corte da peça de madeira (radial ou tangencial);

- torcimento, cujas causas podem ser as mesmas mencionadas para o encanoamento, e também ser gerado pela combinação de contrações diferentes e desvios da grã (espiralada, diagonal, intercruzada, ondulada); 
- arqueamento, causado pela diferença na contração longitudinal entre laterais, da mesma peça de madeira;

- encurvamento, que também ocorre devido as diferenças de retração nas faces da peça quando uma delas sofre mais secagem que a outra, irregularidades da grã e tensões desenvolvidas durante o crescimento da árvore;

- forma diamante, que é um defeito característico de peças com secção quadrada, resultante da diferença entre as contrações tangencial e radial, quando os anéis de crescimento vão, diagonalmente, de um canto ao outro da secção;

Para Oliveira (1981), as técnicas de prevenção dos empenamentos devem ser iniciadas logo no primeiro manuseio da madeira, após a operação de desdobro. $\mathrm{Na}$ preparação das pilhas para secagem, conforme comentado anteriormente, recomenda-se a formação de pilhas planas, utilizando separadores com idênticas dimensões, e atentando-se para o correto posicionamento dos mesmos.

As rachaduras, de acordo com Oliveira (1981) e Galvão \& Jankowsky (1985), aparecem como conseqüência da diferença de retração nas direções radial e tangencial da madeira e de diferenças de umidade entre regiões contíguas de uma peça, durante o processo de secagem. Estas diferenças levam ao aparecimento de tensões que, tornando-se superiores à resistência dos tecidos lenhosos, provocam a ruptura da madeira. STCP (1990) salienta que as rachaduras são mais comuns em madeiras de massa específica mais alta, madeiras menos permeáveis e em peças mais espessas, sendo formadas no início e acentuadas durante a secagem. Portanto, quando elas ocorrerem, deve-se alterar o programa de secagem principalmente na sua fase inicial, diminuindo a temperatura e aumentando a umidade relativa. A madeira pode apresentar três tipos de rachaduras durante a secagem:

- rachaduras de topo, que aparecem nos extremos das peças e, de acordo com Martins (1988), são causadas pela secagem rápida destas partes em relação ao resto da peça. Neste caso, os extremos começam a contrair rapidamente e como o restante da peça não acompanha, ocorrem as rachaduras que, em casos mais sérios, podem transformarse em verdadeiras fendas; 
- rachaduras superficiais, que normalmente ocorrem no período inicial de secagem (Oliveira, 1981), principalmente quando a umidade relativa do ar atinge valores muito baixos (menores que 50\%) gerando, assim, uma acelerada evaporação da região superficial. Segundo Galvão \& Jankowsky (1985), estas rachaduras podem aparecer quando as condições de secagem são muito severas, isto é, baixas umidades relativas, provocando a rápida secagem das camadas superficiais até valores inferiores ao PSF, enquanto as camadas internas estão ainda com mais de $30 \%$ de umidade. Como as camadas internas impedem as superficiais de se retrairem, aparecem tensões que, excedendo a resistência da madeira à tração perpendicular às fibras, provocam o rompimento dos tecidos lenhosos.

- rachaduras internas ou em favos de mel, que podem resultar de rachaduras superficiais que se fecharam ou de rupturas por tração no interior da peça (Ponce \& Watai, 1985). De acordo com Kollmann ${ }^{3}$, citado por Brandão (1989), as rachaduras internas aparecem, principalmente, em madeiras mais densas que foram secas à temperatura excessivamente elevada e cuja resistência à tração transversal seja inferior as tensões de secagem. Segundo Oliveira (1981) e Galvão \& Jankowsky (1985), as rachaduras internas também podem estar associadas com o colapso e o endurecimento superficial. Em muitos casos, este tipo de defeito não é visivel na superfície e no topo da peça e, somente após o processamento (corte), poderá ser observado. Uma vez desenvolvidas, as rachaduras internas não poderão ser eliminadas e, na grande maioria dos casos, a madeira não poderá ser utilizada.

Segundo Martins (1988), os empenamentos e rachaduras, de uma maneira geral, são causados por diferenças de contração da madeira ao secar (resultantes da anisotropia do material ou dos gradientes de umidade desenvolvidos durante o processo) e por tensões de crescimento.

Um outro tipo de defeito que reflete uma retração anormal da madeira é o colapso, caracterizado por ondulações nas superfícies das peças, que podem apresentar-

\footnotetext{
${ }^{3}$ KOLLMANN, F. Investigation sobre las origenes de los defectos de secado de madera de roble verde. Estocolmo, Träforskninginstitut, $1950.2 \mathrm{lp}$.
} 
se bastante distorcidas. De acordo com Jankowsky (1995), a principal causa do colapso é a tensão capilar, que se manifesta nas fases iniciais de secagem, quando a umidade da madeira está acima do PSF. De uma forma geral, os fatores que influenciam no colapso são: pequeno diâmetro dos capilares e das pontoações, altas temperaturas no início da secagem, baixa massa especifica da madeira e alta tensão superficial do líquido que é removido da madeira.

Oliveira (1981) afirma que o desenvolvimento do colapso requer que um considerável número de células da madeira esteja completamente saturada com água, não havendo espaço para o ar e que a madeira apresente baixa permeabilidade.

De acordo com STCP (1990), a intensidade de colapso aumenta com a temperatura, portanto, para diminuir sua intensidade deve-se reduzir a temperatura de secagem, pelo menos até a madeira atingir o PSF. A temperatura máxima neste início não deve ultrapassar $50^{\circ} \mathrm{C}$.

Por último deve ser considerada a ocorrência do endurecimento superficial, que segundo $\mathrm{Mcmillen}^{4}$, citado por Brandão (1989), é causado devido aos esforços de tração e compressão que ocorrem na madeira durante o processo de secagem. Oliveira (1981) e Galvão \& Jankowsky (1985) explicam que este defeito é causado, basicamente, por secagem muito rápida e desuniforme. Uma secagem rápida da madeira, com umidade superior ao PSF, faz com que as suas camadas externas atinjam rapidamente baixos valores de umidade. Em conseqüência, estas camadas ficam sob o efeito de esforços de tração, enquanto a parte central, estando acima do PSF, não se retrai e fica sob compressão. Continuando a secagem, nas mesmas condições, a parte central passa a uma umidade menor que o PSF e começa a retrair-se. Entretanto, esta retração não é acompanhada pelas camadas externas, ocasionando a sua compressão. Essa situação permanece mesmo depois da madeira atingir um teor uniforme de umidade. $O$ processo de endurecimento superficial pode originar rachaduras internas do tipo favo de mel.

${ }^{4}$ McMILLEN, J. M. Drying stress in red oak. Forest Products Journal, v. 5, n. I, p. 71-76, 1955. 
Diversos autores afirmam que o endurecimento superficial poderá ser reduzido ou eliminado se, ao final da secagem, a madeira for submetida a um tratamento com vapor (condicionamento); deixando-a exposta, por determinados períodos de tempo, à elevadas umidades relativas.

\subsection{Programas de Secagem}

A escolha do programa de secagem é um fator determinante para que a secagem convencional ocorra de maneira adequada.

Um programa de secagem consiste num plano para se aplicar a combinação adequada de temperatura e umidade relativa à carga de madeira na estufa, visando reduzir a umidade da madeira até um teor pré-determinado, com o mínimo de defeitos (Martins, 1988 e Galvão \& Jankowsky, 1985).

De acordo com STCP (1990), cada espécie apresenta um melhor comportamento a uma determinada temperatura e umidade relativa. Em termos gerais, pode-se afirmar que a temperatura deve ser baixa e a umidade relativa alta para materiais que são mais propensos a apresentar defeitos.

Os principais fatores envolvidos na escolha de um programa de secagem são: espécie de madeira (massa especifica, permeabilidade, contração, etc); umidade inicial e final; espessura do material; uso a que se destina; e equipamento de secagem (Martins, 1988).

Os programas do tipo umidade-temperatura são os mais comuns na secagem convencional. Neste tipo de programa, a temperatura do ar no interior do secador (e consequentemente a umidade relativa também) é ajustada em função do teor de umidade da madeira (Hildebrand, 1970; Pratt, 1974; Galvão \& Jankowsky, 1985; dentre outros). No programa de secagem podem ser reconhecidas três fases distintas.

- aquecimento, em que a madeira é aquecida sem iniciar o processo de secagem propriamente dito. Inicialmente, o ar do interior do secador é aquecido até atingir a temperatura de bulbo seco desejada e a queda na umidade relativa é compensada com 
intensa umidificação. Posteriormente, promove-se o equilibrio térmico entre o ar e a madeira. Como nesta fase é indesejável que a madeira inicie o processo de secagem, utilizam-se umidades relativas elevadas.

- secagem propriamente dita, durante a qual ocorre a retirada de umidade da madeira. Inicialmente, ocorre a remoção da água capilar, onde devem ser utilizadas baixas temperaturas e altas umidades relativas, para prevenir a ocorrência de colapso e rachaduras. A umidade relativa inicial dependerá da espécie em secagem. A temperatura inicial deve ser mantida até que a água capilar da madeira seja removida. Os valores máximos dependem da espécie e da espessura da madeira: para maiores espessuras adotam-se temperaturas mais baixas. A retirada da água higroscópica caracteriza-se pela elevação da temperatura com a redução simultânea da umidade relativa. O periodo de tempo a ser dispendido com a remoção da água higroscópica irá variar com a massa especifica das espécies, espessura das peças, temperatura utilizada e gradiente de umidade.

- uniformização e condicionamento, que são fases necessárias visando homogeneizar o máximo possivel a umidade em todas as peças da pilha e eliminar suas tensões internas, mediante o reumidecimento das camadas superficiais. As tensões internas são eliminadas, de acordo com STCP (1990), pela redução do gradiente de umidade (a diferença de umidade entre o centro e a superfície).

\subsection{Estrutura dos programas de secagem}

A Tabela 1 mostra 2 maneiras diferentes de estruturar um programa de secagem. As fases de uniformização e condicionamento não são mostradas pois dependem da umidade final desejada. A Figura 3 mostra as curvas envolvendo os potenciais de secagem e as etapas dos programas. 
Tabela 1. Programas de secagem para madeira de Jatobá com até $38 \mathrm{~mm}$ de espessura.

\begin{tabular}{|c|c|c|c|c|c|c|c|c|c|c|c|}
\hline \multicolumn{6}{|c|}{ PROGRAMA A (mudanças suaves) } & \multicolumn{6}{|c|}{ PROGRAMA B (mudanças bruscas) } \\
\hline $\begin{array}{l}\text { Umid. } \\
\text { da mad } \\
(\%)\end{array}$ & $\begin{array}{c}\text { Ts } \\
\left({ }^{\circ} \mathrm{C}\right)\end{array}$ & $\begin{array}{c}\mathbf{T u} \\
\left({ }^{\circ} \mathrm{C}\right)\end{array}$ & $\begin{array}{l}\text { UR } \\
(\%)\end{array}$ & $\begin{array}{l}\text { UE } \\
(\%)\end{array}$ & PS & $\begin{array}{l}\text { Umid. } \\
\text { da mad } \\
(\%)\end{array}$ & $\begin{array}{c}\text { Ts } \\
\left({ }^{\circ} \mathrm{C}\right)\end{array}$ & $\begin{array}{c}\text { Tu } \\
\left({ }^{\circ} \mathbf{C}\right)\end{array}$ & $\begin{array}{l}\text { UR } \\
(\%)\end{array}$ & $\begin{array}{l}\text { UE } \\
(\%)\end{array}$ & PS \\
\hline Aquec. & 40,0 & 39,0 & 94 & 21,6 & - & Até 60 & 40,0 & 37,5 & 85 & 17,1 & - \\
\hline até 50 & 40,0 & 39,0 & 94 & 21,6 & - & 60 & 40,0 & 36,5 & 80 & 15,0 & \\
\hline 50 & 40,0 & 39,0 & 94 & 21,6 & 2,31 & 40 & 40,0 & 40,5 & 75 & 13,5 & 2,96 \\
\hline 40 & 40,0 & 38,5 & 91 & 19,8 & 2,02 & 35 & 45,0 & 39,5 & 70 & 12,2 & 2,87 \\
\hline 35 & 40,0 & 37,5 & 85 & 17,0 & 2,06 & 30 & 45,0 & 43,5 & 65 & 11,1 & 2,70 \\
\hline 30 & 40,0 & 36,5 & 80 & 15,1 & 1,99 & 25 & 50,0 & 42,0 & 60 & 9,9 & 2,53 \\
\hline 28 & 42,0 & 38,0 & 77 & 14,0 & 2,00 & 20 & 60,0 & 47,5 & 50 & 7,3 & 2,74 \\
\hline 26 & 45,0 & 40,0 & 73 & 12,8 & 2,03 & 15 & 65,0 & 48,5 & 40 & 6,0 & 2,50 \\
\hline 24 & 48,0 & 42,5 & 71 & 11,9 & 2,02 & \multirow{4}{*}{\multicolumn{6}{|c|}{$\begin{array}{l}\text { Programa A } \rightarrow \text { proposto por Xylema } \\
\text { Programa B } \rightarrow \text { proposto por Pratt }(1974)\end{array}$}} \\
\hline 22 & 51,0 & 44,5 & 67 & 11,0 & 2,00 & & & & & & \\
\hline 20 & 54,0 & 46,5 & 64 & 10,0 & 2,00 & & & & & & \\
\hline 18 & 57,0 & 48,0 & 58 & 8.8 & 2,05 & & & & & & \\
\hline 16 & 60,0 & 49,5 & 55 & 8,1 & 1,98 & \multicolumn{6}{|c|}{ Ts $=$ Temperatura de bulbo seco } \\
\hline 14 & 60,0 & 47,0 & 47 & 6,9 & 2,03 & \multicolumn{6}{|c|}{$\mathrm{Tu}=$ Temperatura de bulbo úmido } \\
\hline 12 & 60,0 & 45,0 & 41 & 6.1 & 1,97 & \multicolumn{6}{|c|}{ UR $=$ Umidade relativa do ar } \\
\hline 10 & 60,0 & 41,0 & 31 & 4,9 & 2,05 & \multicolumn{6}{|c|}{$\mathrm{UE}=$ Umidade de equilibrio } \\
\hline 8 & 60,0 & 37,0 & 23 & 4,0 & 2,00 & \multicolumn{6}{|c|}{ PS = Potencial de secagem } \\
\hline
\end{tabular}

Nota-se que o programa A opera com mudanças suaves ou contínuas das condições de secagem, mantendo o potencial aproximadamente constante; enquanto o programa B trabalha com mudanças mais bruscas e redução do potencial de secagem. A seleção de um programa de secagem irá depender fundamentalmente do tipo de controlador disponível. Quando o controle é manual, normalmente são utilizados os programas com mudanças bruscas. Os sistemas de controle computadorizados podem atuar das duas formas (brusca ou suave), dependendo da capacidade e da programação do computador.

\footnotetext{
${ }^{5}$ XYLEMA Ltda. Biblioteca de programas de secagem. 1996. (não publicado)
} 


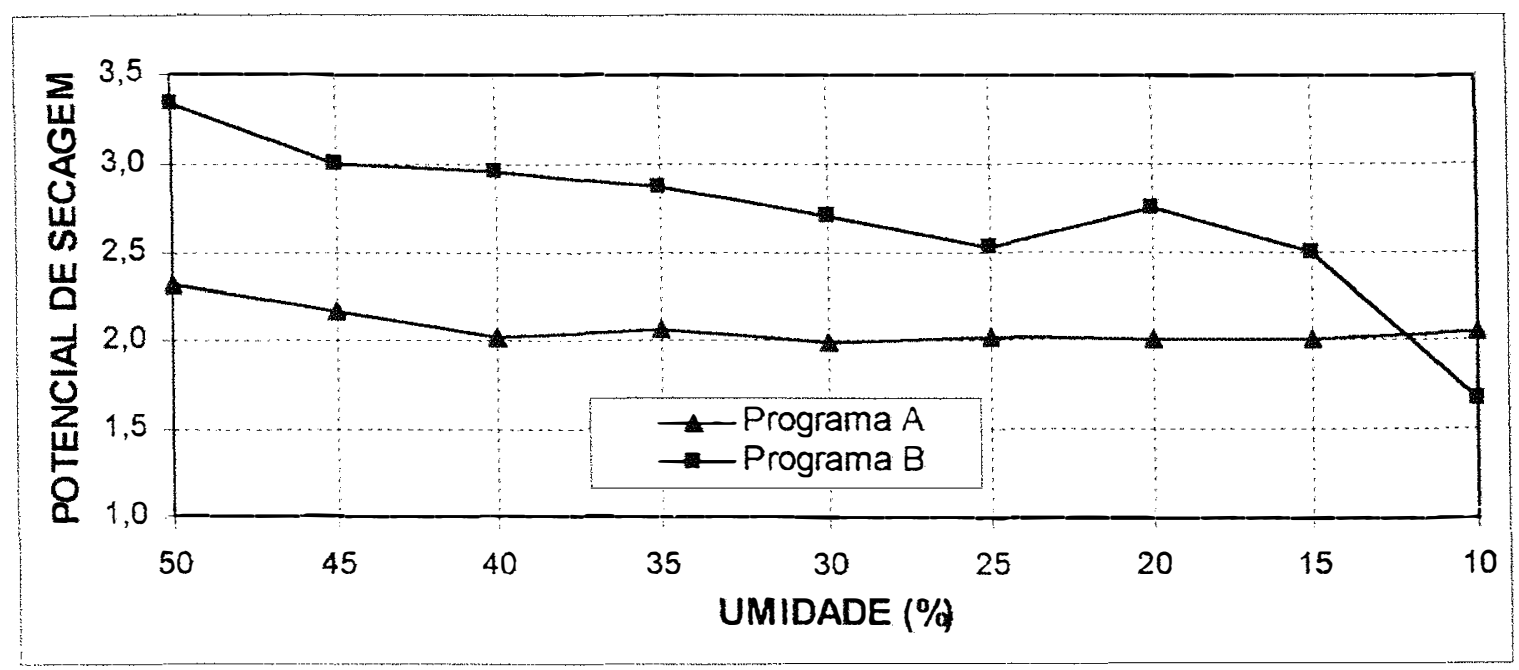

Figura 3 - Potenciais de secagem dos programas A e B (Tabela 1).

De acordo com Denig (1994), as mudanças bruscas de temperatura e umidade de equilíbrio podem favorecer a ocorrência de defeitos. Um exemplo é a ocorrência de rachaduras superficiais quando as amostras chegarem próximas do PSF, onde acontece uma mudança muito drástica nas condições de secagem. Por outro lado, as mudanças suaves nas condições de secagem mantém a velocidade e o potencial de secagem aproximadamente constantes, diminuindo a probabilidade de ocorrência de defeitos.

Little \& Toennisson (1989) compararam secagens conduzidas com programas de mudanças suaves e bruscas. Considerando a duração do processo, as secagens foram semelhantes, entretanto, o programa com mudanças suaves proporcionou ganhos de $6,5 \%$ em termos de energia.

Posteriormente, os mesmos autores (Toennisson \& Little, 1994) efetuaram outro estudo aplicando programas de secagem com mudanças quase que contínuas nas condições de secagem. Estes programas foram elaborados a partir dos programas sugeridos pelo "Forest Products Laboratory" e apresentam entre 20 e 50 pequenas mudanças de temperatura, baseadas na umidade da madeira. Comparando-se com os programas tradicionais, os resultados foram satisfatórios para a secagem de Carvalho Vermelho (Red Oak). Utilizando o programa com mudanças contínuas, o 
tempo de secagem foi reduzido em $32 \%$ e o uso dos controladores computadorizados foi otimizada; entretanto, com relação aos defeitos, novos estudos foram sugeridos. De acordo com Wengert \& Denig (1995), a quebra dos programas tradicionais em pequenas fases foi possível, principalmente, a partir da utilização dos controles computadorizados. Entretanto, isto implica em maior investimento.

\subsection{Indicação e modificações nos programas de secagem}

Tanto a indicação de programas tradicionais para espécies pouco conhecidas como o posterior ajuste dos mesmos usualmente seguem a técnica da tentativa e erro. Esta metodologia é lenta e os programas já existentes podem não ser indicados para espécies pouco conhecidas. Assim, pesquisas vêm sendo realizadas visando desenvolver técnicas alternativas que possibilitem elaborar e/ou modificar os programas de secagem.

Hildebrand (1970) salienta que os valores encontrados nos programas de secagem já existentes são guias para a primeira operação de secagem e modificações podem ocorrer com a experiència obtida. Este mesmo autor frisa que os programas, por ele comentados, são baseados em uma velocidade do ar de $2 \mathrm{~m} / \mathrm{s}$ e as condições de secagem são aplicadas para peças com $30 \mathrm{~mm}$ de espessura. Para peças mais espessas, condições mais suaves, que geram gradientes de secagem menos acentuados, devem ser empregadas.

De acordo com Rasmussen (1961), os programas básicos para espécies folhosas são usados para secar madeira desde a condição úmida, entretanto, eles podem sofrer modificações para aplicação em materiais já secos ao ar. Este mesmo autor recomenda que pilhas de madeira secas ao ar não devem sofrer vaporizações no início da secagem, pois podem ocorrer rachaduras superficiais e empenamentos.

Este mesmo autor salienta que, quando certa espécie é submetida a um programa e não apresenta defeitos significativos, modificações podem ser feitas visando redução no tempo de secagem. Possivelmente, o material pode ser submetido a um 
programa mais severo, entretanto, as modificações devem ser feitas quando o material vier da mesma fonte e para equipamentos específicos.

A primeira modificação no programa é diminuir a temperatura de bulbo úmido, que deve ser feita quando a madeira perder $1 / 3$ de sua umidade. Mudanças subsequentes podem ser feitas a cada diminuição de $10 \%$ do teor de umidade. Posteriormente, pode-se mudar a temperatura de bulbo seco, principalmente no caso de madeiras com características permeáveis que não favoreçam a ocorrência de defeitos. Neste caso, um pequeno aumento na temperatura inicial é permissivel.

As temperaturas também podem ser modificadas nas etapas intermediárias do programa e no finnal da secagem, quando as amostras controladoras atingirem $15 \%$. Neste caso, temperaturas de até $94^{\circ} \mathrm{C}$ podem ser empregadas sem danos à madeira, exceto por uma pequena diminuição da resistência mecânica.

Denig (1994) comenta que os programas sugeridos por Rasmussen (1961) apresentam dois inconvenientes: mudanças bruscas nas condições de secagem e baixas umidades de equilibrio no final dos programas.

Pratt (1974) frisa que o tempo de secagem poderá ser reduzido pela elevação de temperatura de bulbo seco em $5{ }^{\circ} \mathrm{C}$ e/ou diminuição da umidade relativa de $5 \%$ em cada etapa do programa original. Caso os resultados obtidos sejam satisfatórios, modificações podem ser feitas, gradualmente, até que um programa ótimo seja estabelecido.

Bangi et al. (1991) descrevem uma técnica de efetuar modificações em programas de secagem baseada em relações matemáticas que envolvem a umidade da madeira e pressões de vapor. Entretanto, esta técnica visa reduzir o tempo de secagem e o consumo de energia, não considerando a possível degradação do material.

Estudos conduzidos por McMillen (1969) mostraram que peças de Quercus rubra, com uma polegada de espessura, podem ser secas empregando-se programas acelerados, sem a geração de defeitos e com redução significativa da duração de secagem, neste caso, em até $29 \%$. A aceleração do programa baseou-se em empregar maiores velocidades do ar e pequenos aumentos na temperatura, no início e quando o 
teor de umidade da madeira estava entre 45 e $18 \%$. No final da secagem, a temperatura sofreu um aumento maior. Estes aumentos foram baseados em dados de deformação e tensão obtidos anteriormente.

Galvão (1976), baseado nas sugestões de Rietz (1970), elaborou um programa de secagem acelerado para madeira de Jatobá (Hymenaea stilbocarpa). No inicío da secagem, as condições de secagem tradicionais eram mantidas, isto é, altas umidades relativas e baixas temperaturas. Posteriormente, a umidade relativa foi reduzida e, quando a madeira atingiu um teor de umidade de $20 \%$, a temperatura foi elevada de $52^{\circ} \mathrm{C}$ para $80^{\circ} \mathrm{C}$. Esta técnica de aceleração foi desenvolvida baseada nas tensões geradas durante a secagem e os resultados obtidos neste trabalho mostraram que a secagem acelerada foi $42 \%$ mais rápida do que a secagem convencional e não acarretou aumento na ocorrência de rachaduras e colapso. Entretanto, foi constatado um aumento no indice de empenamentos, mas o autor explica que isto também ocorreu devido a desuniformidade da espessura das tábuas e irregularidades da grã.

Simpson \& Verrill (1997) estudaram a possibilidade de empregar a massa específica básica para estimar programas de secagem. Em geral os resultados obtidos foram satisfatórios, entretanto, os autores comentam a existència de exceções e este método de estimação deve ser aplicado apenas quando não são conhecidas outras informações sobre a madeira.

Brandão (1989), a partir de estudos desenvolvidos por Terazawa ${ }^{6}$, propôs uma metodologia de indicação de programas de secagem baseada na relação entre os defeitos decorrentes de uma secagem a $100^{\circ} \mathrm{C}$ e os parâmetros do programa de secagem (temperatura inicial, temperatura final e potencial de secagem). Estes estudos envolvem a hipótese de que pequenas amostras de madeira, quando submetidas a condições severas de secagem, irão apresentar defeitos em um nivel proporcional ao esperado em uma secagem convencional.

\footnotetext{
${ }^{6}$ TERAZAWA, S. Methods for easy determination of kiln drying schedule of wood. Wood Industry, v.20, n.5, 1965.
} 
Ciniglio (1998) desenvolveu programas de secagem para Eucalyptus grandis e Eucalyptus urophilla adaptando a metodologia descrita por Brandão (1989). Os resultados foram considerados satisfatórios, com reduzida ocorrência de defeitos.

\subsection{Grupamento de madeiras para secagem convencional}

O grupamento de diferentes espécies para secagem convencional pode ser considerado um procedimento necessário principalmente para as empresas que secam madeiras tropicais nativas, devido à escassez cada vez maior de matéria-prima. Alguns trabalhos têm analisado a possibilidade de grupar diferentes espécies em um mesmo programa de secagem.

Durand (1985), relacionando características de massa específica e contração das madeiras com temperatura e gradiente de secagem, desenvolveu equações que permitem elaborar programas básicos de secagem. Neste estudo, 50 espécies foram agrupadas em 7 programas que são classificados desde muito lento até muito rápido.

Simpson \& Baah (1989) aplicaram um modelo matemático para grupar espécies na secagem. O modelo correlacionou o tempo de secagem com a massa específica básica, teor de umidade inicial e final, espessura das peças, temperatura e umidade de equilíbrio.

Mendes et al.(1995) gruparam 6 espécies amazônicas em 2 ou 3 grupos considerando características como tempo de secagem e de absorção de água, espessura e temperatura. 


\section{MATERIAL E MÉTODOS}

\subsection{Espécies}

Para os ensaios e posterior indicação dos programas de secagem foram estudadas as espécies listadas na Tabela 2. Essas madeiras estão sendo utilizadas no mercado e foram obtidas em serrarias situadas nas regiões Sul e Sudeste do Brasil.

Tabela 2. Relação de espécies.

\begin{tabular}{ccc}
\hline NOME COMUM & NOME CIENTÍFICO & FAMÍLIA \\
\hline Eucalipto grandis & Eucalyptus grandis W. Hill ex Maiden & Myrtaceae \\
Eucalipto tereticornis & Eucalyptus tereticornis Sm. & Myrtaceae \\
Freijó & Cordia goeldiana Huber & Boraginaceae \\
Imbuia & Ocotea porosa (Nees \& Mart. ex Nees) L.Barroso & Lauraceae \\
Itaúba & Mezilaurus itauba (Meins.) Taub. ex Mez & Lauraceae \\
Jatobá & Hymenaea sp. & Caesalpiniaceae \\
Jutaí-Cica & Martiodendron sp & Caesalpiniaceae \\
Mandioqueira & Qualea sp & Vochysiaceae \\
Pau-Marfim & Balfourodendron riedelianum (Engl.) Engl. & Rutaceae \\
Peroba-Mica & Aspidosperma sp & Apocynaceae \\
Pinus hondurensis & Pinus caribaea Mor. var. hondurensis Bar. \& Golf. & Pinaceae \\
Tamboril & Enterolobium contortisiliquum (Vell.) Morong & Mimosaceae \\
Tauari & Couratari sp. & Lecythidaceae
\end{tabular}


A identificação das espécies foi realizada com auxílio dos técnicos do Instituto de Pesquisas Tecnológicas (IPT-SP), Divisão de Madeiras - Agrupamento de Anatomia e Identificação de Madeiras.

\subsection{Indicação dos programas de secagem}

A metodologia empregada para indicação do programa de secagem é baseada na hipótese de que, pequenas amostras de madeira, quando submetidas à secagens drásticas, apresentarão comportamentos proporcionais aos que possivelmente ocorrerão na secagem convencional, possibilitando, assim, selecionar programas de secagem de maneira confiável e rápida.

Os parâmetros dos programas foram determinados com base na metodologia descrita em detalhes por Ciniglio (1998).

\subsubsection{Preparação das amostras}

No mínimo, 4 tábuas de cada uma das espécies estudadas, preferencialmente bem úmidas, foram selecionadas ao acaso em diferentes fornecedores. As dimensões mínimas das tábuas eram de $900 \times 150 \times 27 \mathrm{~mm}$ (comprimento, largura e espessura). Após serragem e aplainamento, de cada tábua foram retirados 18 corpos de prova, utilizados para secagem a $100^{\circ} \mathrm{C}$, determinação do teor de umidade inicial e massa específica básica, conforme esquema da Figura 4. Para cada um dos ensaios foram utilizados 24 corpos de prova. 


\begin{tabular}{|c|c|c|c|c|c|c|c|c|c|c|c|}
\hline \multicolumn{2}{|c|}{ A } & \multicolumn{2}{|c|}{ A } & \multicolumn{2}{|c|}{ A } & \multicolumn{2}{|c|}{ A } & \multicolumn{2}{|c|}{ A } & \multicolumn{2}{|c|}{ A } \\
\hline$B$ & C & B & C & B & C & B & C & B & C & B & C \\
\hline
\end{tabular}

A - corpo de prova para secagem a $100^{\circ} \mathrm{C}(100 \times 50 \times 10 \mathrm{~mm})$

B - corpo de prova para determinação da massa especifica básica $(50 \times 50 \times 10 \mathrm{~mm})$

C - corpo de prova para determinação do teor de umidade inicial $(50 \times 50 \times 10 \mathrm{~mm})$

Figura 4 - Esquema de retirada dos corpos de prova.

\subsubsection{Determinação da umidade inicial}

Foi empregado o método gravimétrico, descrito em diversos manuais de secagem (Rasmussen, 1961; Pratt, 1974; Galvão e Jankowsky, 1985); onde as amostras úmidas foram submetidas à secagem em estufa a $103^{\circ} \mathrm{C} \pm 2$ até massa constante, aplicando-se em seguida a equação 3 .

$\mathrm{U}=\left(\frac{\mathrm{m}_{\mathrm{u}}}{\mathrm{m}_{\mathrm{s}}}-1\right) \cdot 100 \quad$ onde:

$\mathrm{U}=$ teor de umidade inicial (\%);

$\mathrm{m}_{\mathrm{u}}=$ massa úmida da amostra $(\mathrm{g})$;

$\mathrm{m}_{\mathrm{s}}=$ massa seca $\mathrm{da}$ amostra $(\mathrm{g})$.

O teor de umidade médio das amostras foi utilizado como teor de umidade inicial estimado para as amostras destinadas ao ensaio a $100^{\circ} \mathrm{C}$, possibilitando, assim, estimar a perda de umidade ao longo do teste. 


\subsubsection{Determinação da massa específica básica}

Foi empregado o método da balança hidrostática, descrito por Barrichello (1983), e expresso pela equação 4.

$\mathrm{me}_{\mathrm{b}}=\left(\frac{\mathrm{m}_{\mathrm{s}}}{\mathrm{m}_{\mathrm{u}}-\mathrm{m}_{\mathrm{i}}}\right) \cdot 100 \quad$ onde:

$\mathrm{me}_{\mathrm{b}}=$ massa específica básica $\left(\mathrm{g} / \mathrm{cm}^{3}\right)$;

$\mathrm{m}_{\mathrm{s}}=$ massa seca da amostra $(\mathrm{g})$

$\mathrm{m}_{\mathrm{u}}=$ massa saturada da amostra $(\mathrm{g})$;

$\mathrm{m}_{\mathrm{i}}=$ massa imersa da amostra saturada em água $(\mathrm{g})$.

\subsubsection{Ensaio para determinação dos programas de secagem}

Os 24 corpos de prova de cada espécie foram submetidos à secagem a $100^{\circ} \mathrm{C}$ em estufa de laboratório, sem sistema de circulação de ar, até que o teor de umidade atingisse cerca de $5 \%$.

Durante a secagem drástica as amostras eram periodicamente pesadas e avaliadas quanto à incidência das rachaduras de topo. O intervalo de tempo entre as medições variou de 1 hora (no início do ensaio, quando a taxa de perda de massa é elevada) a 3 horas (no final do ensaio).

Após a secagem as amostras foram cortadas transversalmente para verificação da ocorrência de rachaduras internas e colapso, sendo então reconduzidas para a estufa a $103^{\circ} \mathrm{C} \pm 2$ até atingirem massa constante, usada no cálculo dos teores reais de umidade e velocidades de secagem, empregando-se as equações (3), (5), (6) e (7). 
$V_{1}=\frac{m_{u}-m_{5}}{T_{1} \cdot 100} \quad$ onde:

$\mathrm{V}_{1}=$ velocidade de secagem da umidade inicial até $5 \%\left(\mathrm{~g} / \mathrm{cm}^{2} \cdot \mathrm{h}\right)$;

$\mathrm{m}_{\mathrm{u}}=$ massa da amostra úmida (umidade inicial) $(\mathrm{g})$;

$\mathrm{m}_{\mathrm{S}}=$ massa da amostra a $5 \%$ de umidade $(\mathrm{g})$;

$\mathrm{T}_{1}=$ tempo de secagem da umidade inicial até 5\% $(\mathrm{h})$;

$100=$ área superficial da amostra $\left(\mathrm{cm}^{2}\right)$

$\mathrm{V}_{2}=\frac{\mathrm{m}_{\mathrm{u}}-\mathrm{m}_{30}}{\mathrm{~T}_{2} \cdot 100} \quad$ onde:

$\mathrm{V}_{2}=$ velocidade de secagem da umidade inicial até $30 \%\left(\mathrm{~g} / \mathrm{cm}^{2} . \mathrm{h}\right)$;

$\mathrm{m}_{\mathrm{u}}=$ massa da amostra úmida (umidade inicial) (g);

$\mathrm{m}_{30}=$ massa da amostra a $30 \%$ de umidade $(\mathrm{g})$;

$\mathrm{T}_{2}=$ tempo de secagem da umidade inicial até $30 \%(\mathrm{~h})$;

100 = área superficial da amostra $\left(\mathrm{cm}^{2}\right)$

$V_{3}=\frac{m_{30}-m_{5}}{T_{3} \cdot 100} \quad$ onde:

$\mathrm{V}_{3}=$ velocidade de secagem de 30 a $5 \%$ de umidade $\left(\mathrm{g} / \mathrm{cm}^{2} \cdot \mathrm{h}\right)$;

$\mathrm{m}_{30}=$ massa da amostra a $30 \%$ de umidade $(\mathrm{g})$;

$\mathrm{m}_{\mathrm{S}}=$ massa da amostra a $5 \%$ de umidade $(\mathrm{g})$;

$\mathrm{T}_{3}=$ tempo de secagem de 30 a $5 \%$ de umidade $(\mathrm{h})$;

$100=$ área superficial da amostra $\left(\mathrm{cm}^{2}\right)$

As rachaduras de topo foram medidas com auxílio de lâminas calibradoras de 0,05 a $1,00 \mathrm{~mm}$ (largura) e paquímetro digital com precisão de $0,01 \mathrm{~mm}$ (comprimento), considerando sempre a maior intensidade de ocorrência do defeito. A magnitude das rachaduras era então transformada em escore, conforme classificação da Tabela 3. 
Os parâmetros do programa de secagem foram calculados, com base nos valores médios das 24 amostras ensaiadas por espécie, aplicando-se as equações da Tabela 4.

Tabela 3. Escore atribuido a magnitude das rachaduras de topo.

\begin{tabular}{cc}
\hline ESCORE & RACHADURA DE TOPO \\
\hline 1 & Ausente \\
2 & $\mathrm{CR}<5,0$ e $\mathrm{LR}<0,5$ \\
3 & $\mathrm{CR}>5,0$ e $\mathrm{LR}<0,5$ \\
4 & $\mathrm{CR}<5,0$ e $0,5<\mathrm{LR}<1,0$ \\
5 & $\mathrm{CR}>5,0$ e $0,5<\mathrm{LR}<1,0$ \\
6 & $\mathrm{CR}>5,0$ e $\mathrm{LR}>1,0$ \\
\hline
\end{tabular}

Onde: $\quad C R=$ comprimento da rachadura $(\mathrm{mm})$

$L R=$ largura da rachadura $(\mathrm{mm})$

Tabela 4. Equações para determinação dos parâmetros do programa de secagem.

PARAMETRO

$$
\mathrm{TI}=
$$

$\mathrm{TF}=$

$\mathrm{PS}=$

\section{EQUAÇ̃̃O}

$$
\begin{gathered}
27,9049+0,7881 \mathbf{T} 2+419,0254 \mathbf{V} \mathbf{1}+1,9483 \mathbf{R} 1 \\
49,2292+1,1834 \mathbf{T} 2+273,8685 \mathbf{V} 2+1,0754 \mathbf{R} 1 \\
1,4586-3 \mathbf{0} 4418 \mathbf{V 3}+42,9653 \mathbf{V} \mathbf{1}+\mathbf{0}, 1424 \mathbf{R} 3
\end{gathered}
$$

Onde: $\quad T I=$ temperatura inicial $\mathrm{TF}=$ temperatura final $\mathrm{PS}=$ potencial de secagem
$\mathrm{T} 2$ = tempo de secagem da umidade inicial a $30 \%(\mathrm{~h})$ $\mathrm{V} 1=$ velocidade de secagem ate $5 \%\left(\mathrm{~g} / \mathrm{cm}^{2} . \mathrm{h}\right)$ $V 2=$ velocidade de secagem ate $30 \%\left(\mathrm{~g} / \mathrm{cm}^{2} . \mathrm{h}\right)$ $\mathrm{V} 3=$ vel $\bullet$ cidade de secagem de 30 a $5 \%\left(\mathrm{~g} / \mathrm{cm}^{2} . \mathrm{h}\right)$ $\mathrm{R} 1=$ rachadura de topo até $5 \%\left(\mathrm{Un}_{\mathrm{n}}\right.$.) $\mathrm{R} 3=$ rachadura de topo de 30 a $5 \%$ (Un.)

Com base nos parâmetros encontrados, os programas de secagem foram elaborados com o auxílio de cartas psicrométricas, mas poderiam ter sido também selecionados a partir de programas padrões já existentes na literatura. 


\subsection{Avaliação dos programas de secagem}

Das 13 espécies em estudo, foi feita a secagem convencional da madeira de Freijó, Imbuia, Jutaí-Cica e Peroba-Mica, seguindo-se os programas determinados com auxílio da metodologia descrita em 4.2.4. Essas 4 espécies foram escolhidas devido a disponibilidade de material.

A secagem foi conduzida em um secador da marca Hildebrand modelo $\mathrm{HD} 4004$, com capacidade para $0,1 \mathrm{~m}^{3}$ de madeira e controle semi-automático. O acompanhamento do processo seguiu as recomendações básicas dos manuais de secagem (Rasmussen, 1961; Pratt, 1974; Galvão e Jankowsky, 1985), utilizando-se 5 amostras de controle.

O teor de umidade das amostras de controle foi medido, ao longo da secagem, com um medidor elétrico tipo resistência (Lignomat, modelo K100) e por gravimetria.

A qualidade da secagem foi avaliada através da ocorrência de defeitos, da variação do teor de umidade final e da presença de tensões residuais. A freqüência dos defeitos foi classificada de acordo com a Tabela 5.

Tabela 5. Classificação da tendência ao aparecimento de defeitos.

\begin{tabular}{cc} 
AMOSTRAS QUE & TENDÊNCIA \\
APRESENTARAM DEFEITOS (\%) & \\
\hline 0 a 10 & ausente \\
11 a 30 & pequena \\
31 a 50 & moderada \\
51 a 100 & grande \\
\hline
\end{tabular}

Fonte: Brasil, 1988.

A ocorrência de empenamentos e colapso foi quantificada (presença ou ausência do defeito). As rachaduras, além de quantificadas, foram classificadas, como mostra a Tabela 6 , em função do comprimento da rachadura e da tábua, considerando-se 
a maior intensidade do defeito, nos extremos e/ou em ambas as faces da peça (Martins, 1986).

Tabela 6. Classificação das rachaduras após secagem convencional (Martins, 1986).

\begin{tabular}{cc} 
MAGNITUDE & CLASSIFICAC $\tilde{\mathbf{O}}$ \\
\hline $\mathrm{R} \leq 2,5 \%(\mathrm{CT})$ & normal \\
$2,5 \%<\mathrm{R} \leq 5 \%(\mathrm{CT})$ & média \\
$\mathrm{R}>5 \%(\mathrm{CT})$ & forte \\
\hline Onde: & $\mathrm{R}=$ comprimento da rachadura \\
$\mathrm{CT}=$ comprimento da tábua &
\end{tabular}

A avaliação da qualidade também envolveu a realização de ensaios para determinação da umidade média, distribuição de umidade entre e dentro das peças e verificação das tensões internas. As Figuras 5 e 6 mostram a retirada das amostras e a classificação das tensões. Para verificação do teor e distribuição de umidade foi empregado o método gravimétrico (equação 3) e utilizadas as amostras A e B. No caso das tensões foi utilizada a amostra $C$. 


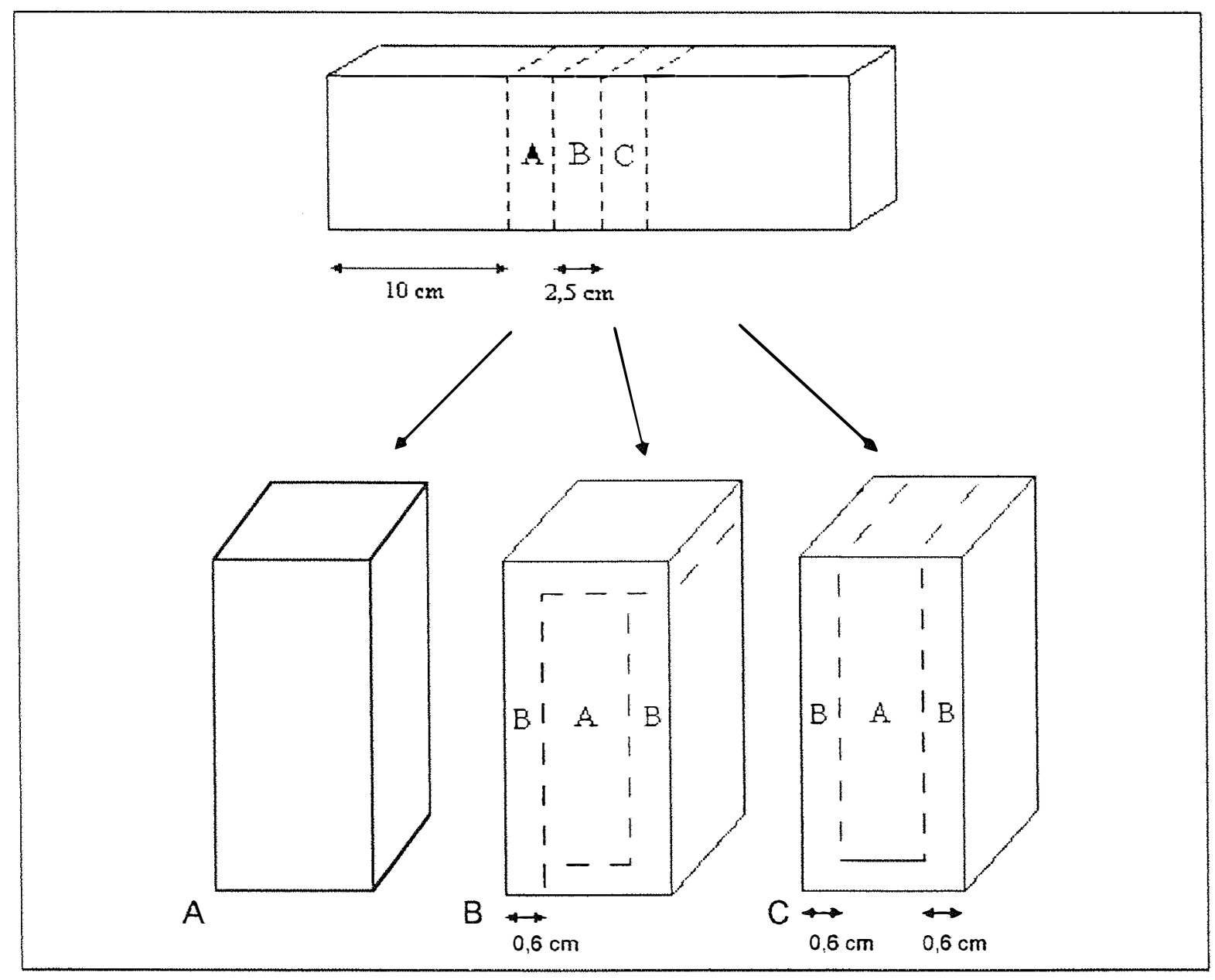

Figura 5 - Retirada dos corpos de prova para os testes de qualidade (Rasmussen, $1961 \mathrm{e}$ Ciniglio, 1998).

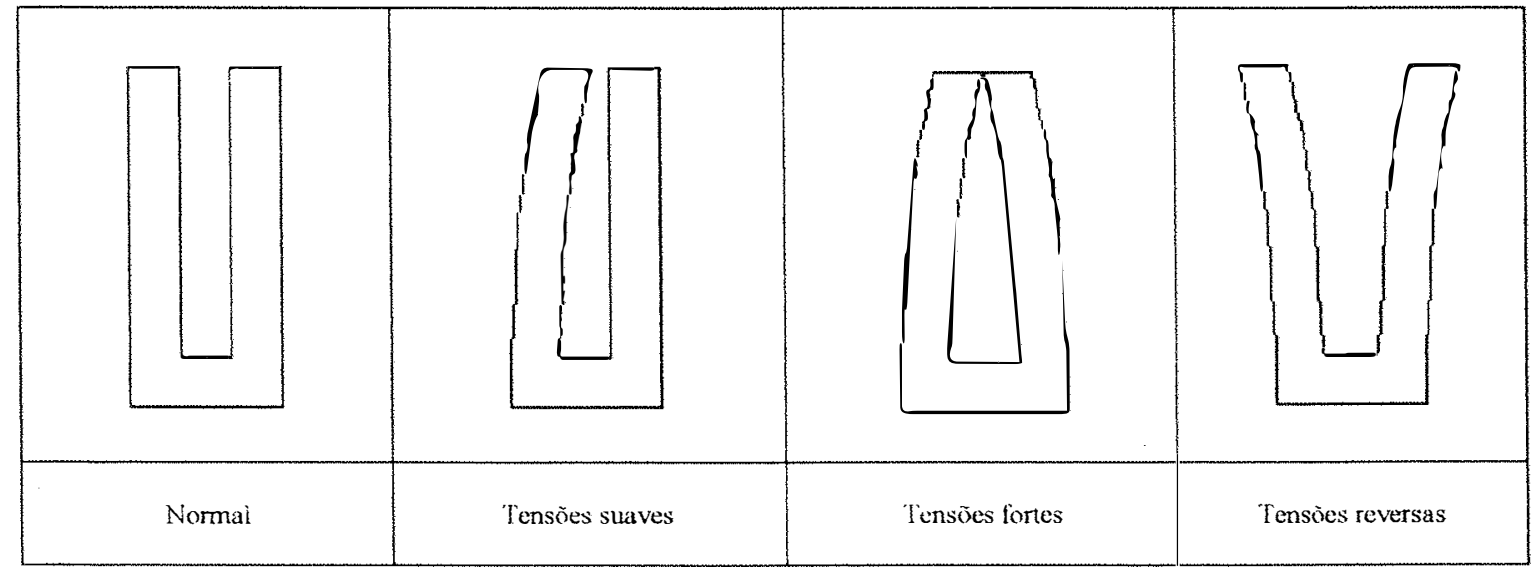

Figura 6 - Classificação das tensões de secagem (Pratt, 1974 e Ciniglio, 1998). 
Os programas indicados para as madeiras de Eucalipto grandis, Jatobá, Pau-Marfim, Pinus hondurensis e Tauari foram comparados com as indicações existentes na literatura. Para as demais espécies (Eucalipto tereticornis, Itaúba e Tamboril) não foi possível avaliar os programas indicados, em função da carência de material e informações disponíveis. 


\section{RESULTADOS E DISCUSSÃO}

\subsection{Parâmetros dos programas de secagem}

A Tabela 7 relaciona os valores médios da umidade inicial, da massa específica básica e das variáveis utilizadas para determinar os parâmetros dos programas de secagem, que são mostrados na Tabela 8. Nos Apêndices 1 e 2 são apresentados os valores médios, com as respectivas amplitudes de variação, de todas as variáveis. 
Tabela 7. Valores médios do teor de umidade inicial, da massa específica básica e das variáveis do ensaio a $100^{\circ} \mathrm{C}$.

\begin{tabular}{|c|c|c|c|c|c|c|c|c|c|}
\hline ESPÉCIE & $\begin{array}{c}\mathrm{Ui} \\
(\%)\end{array}$ & $\begin{array}{c}\mathrm{me}_{\mathrm{b}} \\
(\mathrm{g} / \mathrm{cm})\end{array}$ & $\begin{array}{l}\text { T2 } \\
\text { (h) } \\
\end{array}$ & $\begin{array}{c}V 1 \\
\left(\mathrm{~g} / \mathrm{cm}^{2} . \mathrm{h}\right)\end{array}$ & $\begin{array}{c}V^{2} \\
\left(\mathrm{~g} / \mathrm{cm}^{2} \cdot \mathrm{h}\right)\end{array}$ & $\begin{array}{c}V 3 \\
\left(\mathrm{~g} / \mathrm{cm}^{2} . \mathrm{h}\right)\end{array}$ & $\begin{array}{c}\text { R1 } \\
\text { (Un.) }\end{array}$ & $\begin{array}{c}\text { R2 } \\
\text { (Un.) }\end{array}$ & $\begin{array}{c}\mathbf{R 3} \\
\text { (Un.) } \\
\end{array}$ \\
\hline Eucalipto grandis & 84,5 & 0,54 & 4,41 & 0,0186 & 0,0359 & 0,0186 & 1,33 & 1,29 & 1,33 \\
\hline Eucalipto tereticornis & 48,3 & 0,80 & 2,84 & 0,0107 & 0,0283 & 0,0073 & 2,25 & 2,25 & 2,21 \\
\hline Freijó & 49,5 & 0,56 & 1,93 & 0,0123 & 0,0305 & 0,0085 & 1,17 & 1,17 & 1,08 \\
\hline Imbuia & 97,2 & 0,55 & 9,56 & 0,0114 & 0,0239 & 0,0047 & 1,13 & 1,13 & 1,00 \\
\hline Itaúba & 67,8 & 0,69 & 8,96 & 0,0085 & 0,0171 & 0,0049 & 3,00 & 3,00 & 2,63 \\
\hline Jatobá & 52,6 & 0,78 & 2,53 & 0,0119 & 0,0336 & 0,0082 & 2,25 & 2,13 & 2,21 \\
\hline Jutaí-Cica & 48,6 & 0,87 & 2,47 & 0,0172 & 0,0403 & 0,0112 & 1,00 & 1,00 & 1,00 \\
\hline Mandioqueira & 68,9 & 0,65 & 2,68 & 0,0298 & 0,0537 & 0,0177 & 2,75 & 2,63 & 2,71 \\
\hline Pau-Marfim & 57,8 & 0,65 & 2,27 & 0,0177 & 0,0432 & 0,0108 & 1,75 & 1,75 & 1,63 \\
\hline Peroba-Mica & 70,6 & 0,60 & 2,91 & 0,0217 & 0,0446 & 0,0119 & 2,50 & 2,08 & 2,04 \\
\hline Pinus hondurensis & 162,7 & 0,41 & 3,54 & 0,0495 & 0,0786 & 0,0168 & 2,75 & 2,75 & 2,67 \\
\hline Tamboril & 77,8 & 0,41 & 2,99 & 0,0191 & 0,0347 & 0,0103 & 1,00 & 1,00 & 1,00 \\
\hline Tauari & 59,6 & 0,59 & 2,45 & 0,0195 & 0,0336 & 0,0096 & 2,17 & 2,17 & 1,63 \\
\hline
\end{tabular}

Onde: $\quad \mathrm{Ui}_{\mathrm{i}}=$ umidade inicial

$\mathrm{Vl}=$ velocidade de secagem da Ui até $5 \%$

$\mathrm{Rl}=$ rachaduras de topo da Ui até $5 \%$

$\mathrm{me}_{\mathrm{b}}=$ massa especifica básica

$\mathrm{V} 2=$ velocidade de secagem da Ui até $30 \%$

R2 = rachaduras de topo da Ui até 30\%

$\mathrm{R} 3$ = rachaduras de topo de 30 até $5 \%$ 
Tabela 8. Parâmetros dos programas de secagem.

\begin{tabular}{cccc}
\hline \multirow{2}{*}{ ESPÉCIE } & \multicolumn{3}{c}{ PARÂMETROS } \\
\cline { 2 - 4 } & $\begin{array}{c}\text { Temp. } \\
\text { inicial } \\
\left({ }^{\circ} \mathbf{C}\right)\end{array}$ & $\begin{array}{c}\text { Temp. } \\
\text { final } \\
\left({ }^{\circ} \mathbf{C}\right)\end{array}$ & $\begin{array}{c}\text { Potencial } \\
\text { de secagem }\end{array}$ \\
\hline Eucalipto grandis & 41,7 & 65,7 & 2,17 \\
Eucalipto tereticornis & 39,0 & 62,7 & 2,01 \\
Freijó & 36,8 & 61,1 & 1,88 \\
Imbuia & 42,4 & 68,3 & 1,95 \\
Itaúba & 44,4 & 67,7 & 2,05 \\
Jutai-Cica & 39,0 & 64,3 & 2,00 \\
Jatobá & 39,0 & 63,8 & 2,03 \\
Mandioqueira & 47,6 & 70,1 & 2,59 \\
Pau-Marfim & 40,5 & 65,6 & 2,12 \\
Peroba-Mica & 43,3 & 67,6 & 2,32 \\
Pinus hondurensis & 56,8 & 77,9 & 3,45 \\
Tamboril & 40,2 & 62,3 & 2,11 \\
Tauari & 42,2 & 64,5 & 2,15 \\
\hline
\end{tabular}

De uma forma geral, os parâmetros determinados mostram-se coerentes, comprovando a adequação da metodologia. Um exemplo disto são os valores elevados encontrados para o Pinus, que é uma espécie geralmente de rápida secagem e os valores menores para o Eucalipto, que é uma espécie reconhecidamente de difícil secagem.

Como pode-se observar na Tabela 8, algumas espécies apresentaram valores dos parâmetros bastante aproximados, o que permite indicar o mesmo programa de secagem básico. Embora diferentes espécies possam ser grupadas, com a indicação de um programa único, não significa que as madeiras apresentarão o mesmo comportamento quando em secagem. 
A possível diferença de comportamento entre espécies de um mesmo grupo pode ser estimada, como exemplo, para as madeiras de Tauari e Pau-Marfim; que apresentam umidades iniciais aproximadas e uma velocidade de secagem na faixa de umidade capilar de 0,0336 e $0,0432 \mathrm{~g} / \mathrm{cm}^{2} . \mathrm{h}$, respectivamente. Embora possam ser grupadas em um mesmo programa de secagem, uma simulação prática (considerando-se a secagem de tábuas com $250 \times 10 \times 2,5 \mathrm{~cm}$ ) mostra que a massa de água removida em $1 \mathrm{~m}^{3}$ de madeira seria de $26,88 \mathrm{~kg} / \mathrm{h}$ no caso do Tauari e $34,56 \mathrm{~kg} / \mathrm{h}$ para o Pau-Marfim, refletindo a diferença de 30\% na taxa de secagem individual das espécies consideradas. Neste caso, a secagem conjunta dessas espécies deve ser controlada pela madeira de Tauari, que apresenta uma secagem mais lenta.

Um outro exemplo pode ser observado entre as madeiras de Eucalipto tereticornis e Jutaí-Cica, que apresentaram massas específicas e parâmetros do programa de secagem similares. Considerando as velocidades de secagem entre 30 e 5\% de umidade (Tabela 27 - Apêndice 1), a do Jutaí-Cica foi cerca de 53\% maior em comparação ao Eucalipto tereticornis. A secagem conjunta dessas espécies deve ser controlada por amostras de Eucalipto tereticornis.

Com relação à ocorrència de rachaduras, verifica-se claramente que as madeiras de Tamboril e Jutaí-Cica são menos suscetíveis à incidência desse defeito. Assim, provavelmente essas espécies poderão ser submetidas à secagem com condições mais severas do que as indicadas no programa de secagem básico (Anexo A), visando reduzir a duração da secagem, conforme recomenda Rasmussen (1961).

Vários autores, como Martins (1988) e Ponce \& Watai (1985) comentam que geralmente as madeiras mais densas requerem mais tempo para secar e tendem a apresentar maiores defeitos. Entretanto, como é observado nas Tabelas 7 e 8, a massa específica básica não é um fator que, isoladamente, deve ser considerado para indicação de programas de secagem, já que não explica as variações existentes. Isto pode ser verificado, observando-se as madeiras de Mandioqueira e Pau-Marfim, que são espécies de mesma massa específica e programas de secagem diferentes. No sentido inverso tem- 
se as madeiras de Pau-Marfim, Tamboril e Tauari que apresentam diferentes massas específicas e podem ser indicadas para o mesmo programa de secagem.

Esta observação permite inferir que outros fatores, além da massa específica, afetam o comportamento da madeira em relação à sua secagem. Considerando-se que a movimentação da água líquida, assim como a movimentação de vapor d'água, ocorre através do lume dos diferentes elementos anatômicos e das pontoações entre esses elementos (Siau, 1984), é válido supor que as diferenças observadas na velocidade de secagem entre espécies de massa especifica similar é decorrente de diferenças na estrutura anatômica e, consequentemente, da permeabilidade das espécies.

A análise dos resultados obtidos permitiu indicar programas de secagem para as espécies estudadas, e também foi possivel grupar espécies diferentes em um mesmo programa de secagem básico. Entretanto, é importante frisar que a secagem conjunta de diferentes espécies deve ser conduzida com muito cuidado, atentando-se para características específicas como teor de umidade inicial, velocidade de secagem e tendência em apresentar defeitos. É recomendável que a secagem conjunta seja controlada pela espécie que apresente maiores dificuldades de secagem, ou seja, maior tendência a defeitos e menor velocidade de secagem.

A partir dos resultados da Tabela 8 foram sugeridos 7 programas de secagem (Anexo A), propostos para as madeiras de Eucalipto tereticornis, Freijó, Jatobá e Jutaí-Cica (Tabela 20), Eucalipto grandis, Pau-Marfim, Tamboril e Tauari (Tabela 21), Imbuia (Tabela 22), Peroba-Mica (Tabela 23), Mandioqueira (Tabela 24), Itaúba (Tabela 25) e Pinus hondurensis (Tabela 26). Esta metodologia permite indicar programas de secagem para peças com espessura de até $28 \mathrm{~mm}$. Para espessura maiores é recomendável a adoção de programas mais suaves.

Com base nas análises efetuadas também pode-se concluir que a massa específica básica não deve ser empregada isoladamente para elaboração de programas de secagem; e que o grupamento de espécies, visando a secagem conjunta, depende também da umidade inicial e da velocidade de secagem. 


\subsection{Secagem convencional das madeiras de Freijó, Imbuia, Jutaí-Cica e Peroba- Mica}

A Tabela 9 mostra as características das espécies que foram submetidas à secagem convencional, conduzida seguindo-se os programas indicados pelo ensaio a $100^{\circ} \mathrm{C}$ (Tabelas 29 a 32 - Apêndice 3).

Tabela 9. Características das madeiras submetidas à secagem convencional.

\begin{tabular}{ccccccc}
\hline ESPÉCIE & $\begin{array}{c}\text { UMIDADE } \\
\text { INICIAL }\end{array}$ & $\mathbf{m e}_{\mathbf{b}}{ }^{*}$ & $\mathbf{N}^{\circ} \mathbf{D E}$ & \multicolumn{3}{c}{ DIMENSÕES (cm) } \\
\hline Freijó & $\mathbf{( \% )}$ & $\left(\mathbf{g} / \mathbf{c m}^{3}\right)$ & PECAS & comprimento & largura & espessura \\
Imbuia & 39,8 & 0,56 & 20 & 50 & $(10$ a 15$)$ & 4,0 \\
Jutaí-Cica & 108,2 & 0,55 & 20 & 50 & $(10$ a 15) & 4,0 \\
Peroba-Mica & 46,8 & 0,78 & 24 & 50 & $(8$ e 19) & 2,3 \\
${ }^{*}$ me $_{\mathrm{h}}=$ Massa especifica básica & & 0,60 & 24 & 50 & $(8$ e 17) & 2,7 \\
\hline
\end{tabular}

${ }^{*} \mathrm{me}_{\mathrm{b}}=$ Massa especifica básica

As curvas de secagem, baseadas nas peças que foram usadas como amostras de controle, podem ser analisadas na Figura 7. Os resultados numéricos (média de toda a carga) constam nas Tabelas 10 e 11, e a duração das diferentes fases da secagem é mostrada na Tabela 12 . 


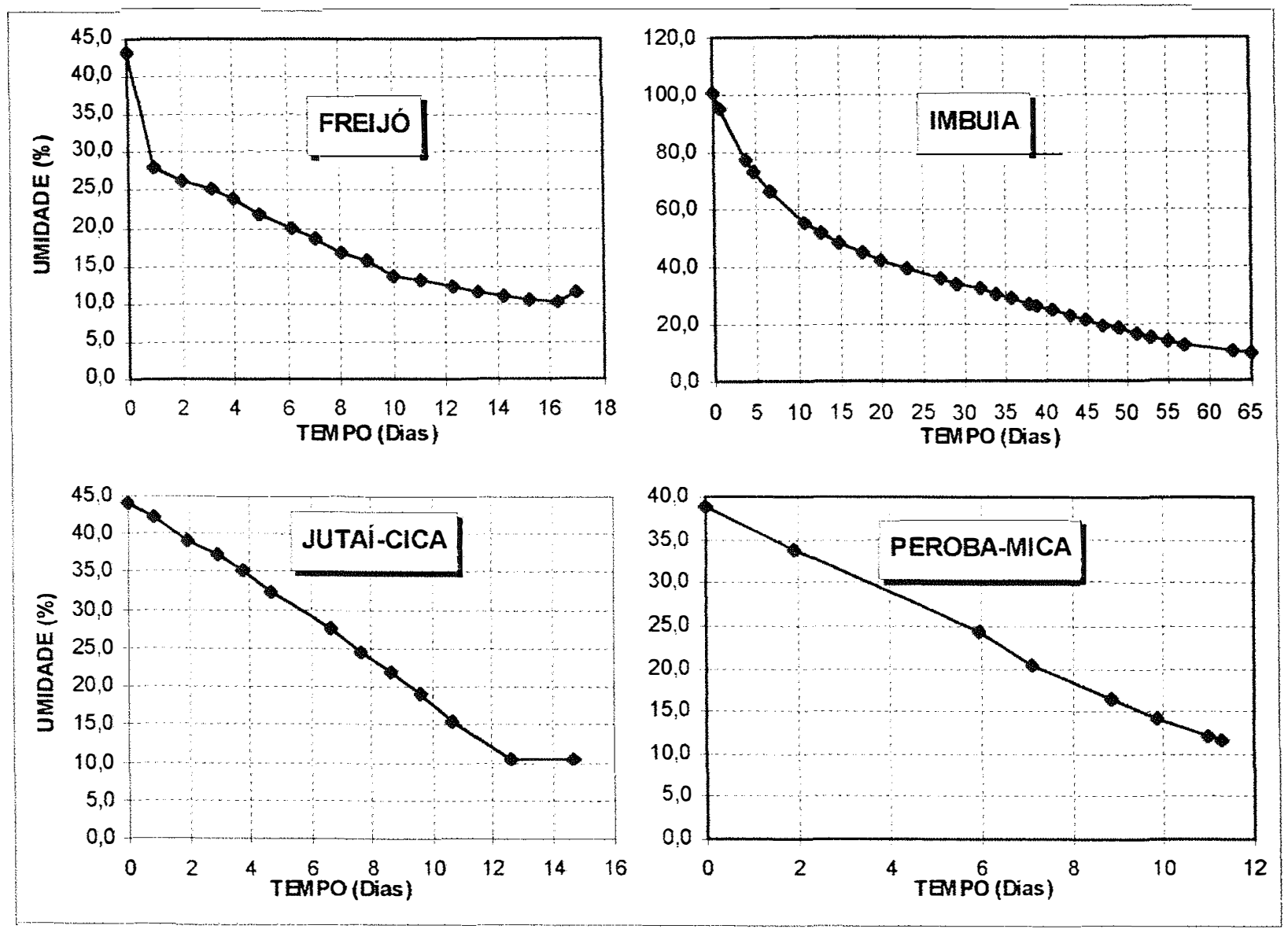

Figura 7 - Curvas de secagem.

Tabela 10. Duração e taxas de secagem.

\begin{tabular}{ccccc}
\hline ESPÉCIE & $\begin{array}{c}\text { UMIDADE } \\
\text { INICIAL } \\
(\%)\end{array}$ & $\begin{array}{c}\text { UMIDADE } \\
\text { FINAL } \\
\mathbf{( \% )}\end{array}$ & $\begin{array}{c}\text { DURAÇ̃O } \\
\text { (dias) }\end{array}$ & $\begin{array}{c}\text { TAXA DE } \\
\text { SECAGEM } \\
(\% / \text { dia) }\end{array}$ \\
\hline Freijó & 39,8 & 10,8 & 17,0 & 1,71 \\
Imbuia & 108,2 & 14,0 & 64,9 & 1,45 \\
Jutai-Cica & 46,8 & 11,9 & 14,7 & 2,37 \\
Peroba-Mica & 30,0 & 10,7 & 11,3 & 1,71 \\
\hline
\end{tabular}


Tabela 11. Velocidades de secagem no ensaio a $100^{\circ} \mathrm{C}$ e na secagem convencional.

\begin{tabular}{|c|c|c|c|c|}
\hline \multirow{3}{*}{ ESPÉCIE } & \multicolumn{4}{|c|}{ VELOCIDADE DE SECAGEM $\left(\mathrm{g} / \mathrm{cm}^{2} . \mathrm{h}\right)$} \\
\hline & \multicolumn{2}{|c|}{ Ensaio a $100^{\circ} \mathrm{C}$} & \multicolumn{2}{|c|}{ Secagem convencional } \\
\hline & $U>30 \%$ & $\mathrm{U}<30 \%$ & $\mathrm{U}>\mathbf{3 0} \%$ & $\mathrm{U}<30 \%$ \\
\hline Freijó & 0,0305 & 0,0085 & 0,0055 & 0,0006 \\
\hline Imbuia & 0,0239 & 0,0047 & 0,0011 & 0,00025 \\
\hline Jutaí-Cica & 0,0403 & 0,0112 & 0,0011 & 0,0009 \\
\hline Peroba-Mica & 0,0446 & 0,0119 & - & 0,0009 \\
\hline
\end{tabular}

Tabela 12. Duração das fases do processo de secagem.

\begin{tabular}{|c|c|c|c|c|c|c|}
\hline \multirow{2}{*}{ ESPÉCIE } & \multicolumn{2}{|c|}{$\mathrm{T}\left({ }^{\circ} \mathrm{C}\right)$} & \multirow{2}{*}{ PS } & \multicolumn{3}{|c|}{ DURAÇÃO (horas) } \\
\hline & inicial & final & & secagem & uniformização & condicionamento \\
\hline Freijó & 40 & 60 & 2,0 & 407 & 144 & 17 \\
\hline Imbuia & 45 & 70 & 1,9 & 1557 & 111 & 48 \\
\hline Jutaí-Cica & 40 & 60 & 2,0 & 353 & 53 & 42 \\
\hline Peroba-Mica & 40 & 70 & 2,2 & 271 & 18 & 6 \\
\hline
\end{tabular}

Conforme pode ser observado, os programas empregados resultaram em secagens lentas. Aparentemente, observando o tempo despendido na secagem, a madeira de Peroba-Mica apresentou uma secagem rápida. Entretanto, deve ser considerado a umidade inicial e a espessura das peças.

De acordo com a Tabela 11, observa-se que, abaixo do PSF, as velocidades obedecem a mesma tendência, ou seja, as madeiras de Jutaí-Cica e PerobaMica apresentam maiores velocidades de secagem do que as madeiras de Freijó e Imbuia, em ambos os ensaios.

No caso da umidade acima do PSF, nenhuma relação foi observada. É provável que as diferenças das umidades iniciais nos diferentes ensaios tenham influenciado os resultados, não permitindo uma análise conclusiva. 
Pelos resultados obtidos na faixa de umidade abaixo do PSF, verifica-se mais uma vez a adequação da metodologia, ou seja, o ensaio a $100^{\circ} \mathrm{C}$ refletiu o comportamento da secagem convencional.

Os programas empregados resultaram em secagens lentas, mas é importante frisar que baixas velocidades de secagem significam redução na probabilidade da ocorrência de defeitos. Adicionalmente, deve-se considerar que o objetivo da metodologia usada (ensaio a $100^{\circ} \mathrm{C}$ ) é indicar programas conservadores, e que devem ser modificados para atender as necessidades específicas dos usuários.

Os resultados referentes à qualidade da madeira seca, avaliada conforme os critérios descritos em 4.3, constam nas Tabelas 13 a 15.

Tabela 13. Porcentagem de peças que apresentaram defeitos.

\begin{tabular}{|c|c|c|c|c|}
\hline \multirow{2}{*}{$\begin{array}{c}\text { DEFEITOS } \\
(\%)\end{array}$} & \multicolumn{4}{|c|}{ ESPÉCIES } \\
\hline & Freijó & Imbuia & Jutaí-Cica & Peroba-Mica \\
\hline torcimento & 0 & 80 & 0 & 21 \\
\hline encanoamento & 0 & 10 & 0 & 0 \\
\hline encurvamento & 0 & 10 & 0 & 0 \\
\hline arqueamento & 0 & 10 & 0 & 0 \\
\hline rach. superficial* & 0 & 15 & 8 & 17 \\
\hline rach. de topo* & 0 & 15 & 0 & 8 \\
\hline rach. interna* & 0 & 15 & 0 & 0 \\
\hline colapso & 0 & 75 & 0 & 0 \\
\hline tensões suaves & 0 & 8,3 & 33,3 & 45,8 \\
\hline tensões fortes & 0 & 33,3 & 66,7 & 20,8 \\
\hline
\end{tabular}

* Todas as rachaduras foram classificadas como fortes. 
Tabela 14. Classificação da incidência de defeitos.

\begin{tabular}{ccccc}
\hline \multirow{2}{*}{ DEFEITOS } & \multicolumn{4}{c}{ TENDENCIA } \\
\cline { 2 - 5 } & Freijó & Imbuia & Jutaí-Cica & Peroba-Mica \\
\hline torcimento & ausente & grande & ausente & pequena \\
encanoamento & ausente & ausente & ausente & ausente \\
encurvamento & ausente & ausente & ausente & ausente \\
arqueamento & ausente & ausente & ausente & ausente \\
rach. superficial & ausente & pequena & ausente & pequena \\
rach. de topo & ausente & pequena & ausente & ausente \\
rach. interna & ausente & pequena & ausente & ausente \\
colapso & ausente & grande & ausente & ausente \\
tensões & ausente & moderada & grande & grande \\
\hline
\end{tabular}

Tabela 15. Distribuição da umidade final (média e amplitude de variação).

\begin{tabular}{cccc} 
ESPÉCIE & média & $\begin{array}{c}\text { UMIDADE }(\%) \\
\text { externa }\end{array}$ & interna \\
\hline Freijó & $10,1(9,3-12,2)$ & $10,2(9,5-10,8)$ & $10,1(9,2-13,2)$ \\
Imbuia & $14,0(10,1-29,8)$ & $11,9(10,1-14,8)$ & $16,4(9,6-42,5)$ \\
Jutaí-Cica & $11,9(10,8-15,1)$ & $10,9(9,7-12,2)$ & $12,2(10,7-16,7)$ \\
Peroba-Mica & $10,7(9,4-13,5)$ & $9,5(9,1-11,0)$ & $10,9(9,2-15,6)$ \\
\hline
\end{tabular}

Uma primeira análise permite constatar que, com exceção da Imbuia, os programas de secagem utilizados foram adequados, resultando em secagens com pequenas incidências de defeitos e distribuições razoavelmente uniformes de umidade, visto que desejava-se uma umidade final em torno de $12 \%$.

É importante salientar que a ocorrência dos empenamentos esta ligada também a fatores como dimensões das peças, tipo de corte e grã da madeira e forma de empilhamento, conforme frisam Oliveira (1981) e Ponce \& Watai (1985). 
Analisando-se individualmente o comportamento das espécies ensaiadas, é possível sugerir alterações para os programas de secagem.

O programa de secagem empregado para a madeira de Freijó pode ser considerado adequado, já que a madeira não apresentou tendência aos defeitos e a uniformidade de umidade foi bastante satisfatória tanto entre como dentro das peças. Em função dos resultados, é possivel indicar um programa mais agressivo (maior potencial de secagem), visando reduzir o tempo de secagem.

Em relação a Imbuia, os resultados mostraram alta incidência de torcimento e colapso ( $80 \%$ e $75 \%$ das peças, respectivamente) e alta desuniformidade de umidade. Esta madeira é uma espécie reconhecidamente de difícil secagem devido à sua estrutura anatômica e química, como vasos de diâmetro reduzido e presença de óleoresina (Mainieri \& Chimelo, 1989). Não é possível afirmar seguramente que o programa de secagem empregado foi adequado ou não, pois trata-se de um programa suave com potencial de secagem em torno de $2 \mathrm{e}$, como pode ser verificado, a duração da secagem foi bastante longa. Outros autores, como Pratt (1974) e Rasmussen (1961), sugerem a utilização de programas mais drásticos, com potenciais de secagem acima de 2,5.

A nivel industrial, caso seja empregado um programa mais suave, os defeitos podem ser minimizados, entretanto, implicará em um longo tempo de secagem e maior gasto de energia, que poderão tomar o processo inviável economicamente.

Neste caso, assim como Vermaas (1995) indica para a madeira de Eucalipto, é recomendável empregar algum sistema de pré-secagem até a madeira atingir o PSF, visando minimizar a ocorrência principalmente do colapso, e posteriormente efetuar secagem em estufa de maneira bem controlada. Além disso, é importante seguir as recomendações de empilhamento adequado visando reduzir os empenamentos.

As madeiras de Peroba-Mica e Jutai-Cica apresentaram comportamento similar. Os programas de secagem usados foram adequados para essas espécies, entretanto, visando principalmente uniformizar a distribuição de umidade das peças e reduzir a presença de tensões, é recomendável secar madeira com uma menor variação 
de umidade no início do processo ou aumentar os períodos de uniformização e condicionamento.

Para reduzir a duração da secagem, sugere-se alterar gradualmente as condições de secagem até que um programa ótimo seja estabelecido.

A madeira de Peroba-Mica apresentou também uma pequena incidência de rachaduras superficiais e torcimento. Recomenda-se suavizar as condições iniciais de secagem e efetuar procedimentos adequados de empilhamento.

Com base nas análises efetuadas pode-se concluir que, com exceção da espécie Imbuia, os programas de secagem utilizados foram adequados, resultando em secagens com pequenas incidèncias de defeitos e distribuições uniformes de umidade. No caso da madeira de Imbuia e de outras madeiras com alta propensão a defeitos é recomendável efetuar pré-secagem antes do processo de secagem convencional.

\subsection{Programas de secagem para Jatobá, Mandioqueira, Pau-Marfim, Pinus hondurensis e Tauari}

A Tabela 16 compara os parâmetros obtidos neste trabalho com indicações disponíveis na literatura especializada para madeiras com até $38 \mathrm{~mm}$ de espessura. Os potenciais de secagem apresentados são correspondentes à faixa de $30 \%$ de umidade da madeira. 
Tabela 16. Comparação dos programas de secagem com informações disponíveis em literatura.

\begin{tabular}{|c|c|c|c|c|}
\hline Espécie & $\begin{array}{c}\text { temperatura } \\
\text { inicial }\left({ }^{\circ} \mathrm{C}\right)\end{array}$ & $\begin{array}{c}\text { temperatura } \\
\text { final }\left({ }^{\circ} \mathrm{C}\right)\end{array}$ & $\begin{array}{c}\text { potencial } \\
\text { de secagem }\end{array}$ & Fonte \\
\hline \multirow{6}{*}{ Jatobá } & 39 & 64 & 2,03 & presente pesquisa \\
\hline & 40 & 60 & 1,99 & Xylema $^{5}$ \\
\hline & 40 & 70 & 2,26 & Xylema $^{5}$ \\
\hline & 50 & 70 & 2,43 & Hildebrand (1970) \\
\hline & 43 & 71 & 2,91 & FPL (1998) \\
\hline & 40 & 65 & 2,96 & Pratt (1974) \\
\hline \multirow{4}{*}{ Mandioqueira } & 48 & 70 & 2,59 & presente pesquisa \\
\hline & 45 & 70 & 2,97 & Xylema $^{5}$ \\
\hline & 40 & 65 & 3,57 & Boone et al. (1988) \\
\hline & 43 & 71 & 5,26 & FPL $(1998)$ \\
\hline \multirow{7}{*}{ Pau-Marfim } & 41 & 66 & 2,12 & presente pesquisa \\
\hline & 45 & 60 & 2,24 & Xylema $^{5}$ \\
\hline & 40 & 70 & 2,26 & Xylema $^{5}$ \\
\hline & 46 & 62 & 2,63 & Brotero (1941) \\
\hline & 49 & 82 & 2,91 & FPL $(1998)$ \\
\hline & 50 & 75 & 2,91 & Boone et al. (1988) \\
\hline & 49 & 82 & 5,26 & Martins (1988) \\
\hline \multirow{4}{*}{ Pinus hondurensis } & 57 & 78 & 3,45 & presente pesquisa \\
\hline & 60 & 75 & 3,85 & Pratt (1974) \\
\hline & 57 & 76 & 3,95 & $\mathrm{FPRL}^{7} *$ \\
\hline & 60 & 82 & 4,55 & Boone et al. (1988) \\
\hline \multirow{4}{*}{ Tauari } & 42 & 64 & 2,15 & presente pesquisa \\
\hline & 60 & 70 & 2,44 & Brasil (1981) \\
\hline & 55 & 70 & 3,00 & Xylema $^{5}$ \\
\hline & 70 & 80 & 4,62 & Martins et al. (1997) \\
\hline
\end{tabular}

* Forest Products Research Laboratory, citado por Mendes et al. (1998)

De uma forma geral, os paràmetros obtidos mostram-se seguros. Verificase que os valores encontrados neste trabalho são similares aos disponiveis na literatura, principalmente para as madeiras de Jatobá e Pinus, comprovando a adequação da metodologia. É importante destacar que esta metodologia visa a indicação de programas

\footnotetext{
7 FOREST PRODUCTS RESEARCH LABORATORY. Kiln-drying schedules. Princes Risborough, 1969. 18p. (Technical Note, 37)
} 
conservadores, isto é, com menores potenciais e condições mais suaves. Esses programas, apesar de aumentarem a duração do processo, reduzem a probabilidade de ocorrência de defeitos. É provável que os programas sugeridos no Anexo A proporcionem secagens adequadas com madeira seca apresentando baixa incidência de defeitos.

\subsection{Programas de secagem para Eucalipto tereticornis, Itaúba e Tamboril.}

Para essas espécies não foi possível realizar ensaios de secagem convencional e comparações com a literatura em função da carência de material e informações disponíveis. Entretanto, com base nos resultados obtidos com as outras madeiras ensaiadas, é possível afirmar que os programas sugeridos no Anexo A podem ser aplicados para essas espécies.

\subsection{Programas de secagem para Eucalipto grandis}

O destaque para o Eucalipto grandis justifica-se pela disponibilidade de informações mais detalhadas do comportamento dessa madeira, submetida à diferentes programas de secagem. Além disso, a tendência de sua utilização é crescente, para os mais diversos usos, sendo necessário estudos buscando melhorar seu aproveitamento.

Conforme trabalho desenvolvido por Jankowsky ${ }^{8}$ et al., foram empregados três programas de secagem distintos para madeira de Eucalipto grandis (40 mm de espessura) com diferentes umidades iniciais. As condições de secagem são mostrados na Tabela 17 .

8 JANKOWSKY, 1.P.; DUCATTI, M.A.; ANDRADE, A. Avaliação da secagem da madeira de Eucalyptus grandis. Piracicaba: ESALQ, Depto. de Ciências Florestais, 1998. 16p. (Relatório Técnico - não publicado) 
Tabela 17. Condições de secagem convencional do Eucalipto grandis (Jankowsky ${ }^{8}$ et al., 1998).

\begin{tabular}{ccccc} 
CONDIÇÃO & $\begin{array}{c}\text { UMIDADE } \\
\text { INICIAL (\%) }\end{array}$ & $\begin{array}{c}\text { TEMPERATURA } \\
\text { INICIAL }\left({ }^{\circ} \mathbf{C}\right)\end{array}$ & $\begin{array}{c}\text { TEMPERATURA } \\
\text { FINAL }\left({ }^{\circ} \mathbf{C}\right)\end{array}$ & $\begin{array}{c}\text { POTENCIAL } \\
\text { DE SECAGEM }\end{array}$ \\
\hline $\mathbf{1}$ & 73,3 & 35,0 & 60,0 & 2,2 \\
$\mathbf{2}$ & 27,3 & 40,0 & 70,0 & 2,5 \\
$\mathbf{3}$ & 19,3 & 45,0 & 70,0 & 3,0 \\
\hline
\end{tabular}

As madeiras secas pelos programas 2 e 3 foram submetidas à présecagem ao ar em ambiente coberto, por períodos de 140 e 220 dias, respectivamente. As condições de secagem, como pode ser observado, vão fĩcando mais rigorosas à medida que a umidade inicial vai diminuindo. A Tabela 18 mostra os resultados com relação aos defeitos.

Tabela 18. Porcentagem de peças de Eucalipto grandis que apresentaram defeitos antes e após a secagem convencional (Jankowsky ${ }^{8}$ et al.,1998).

\begin{tabular}{|c|c|c|c|c|c|c|}
\hline \multirow{3}{*}{$\begin{array}{l}\text { DEFEITOS } \\
\qquad(\%)\end{array}$} & \multirow{2}{*}{\multicolumn{3}{|c|}{$\begin{array}{c}\text { antes da secagem em estufa } \\
\text { condiçã } 0^{*}\end{array}$}} & \multicolumn{3}{|c|}{ após a secagem em estufa } \\
\hline & & & & \multicolumn{3}{|c|}{ condição* } \\
\hline & 1 & 2 & 3 & 1 & 2 & 3 \\
\hline torcimento & 0 & 2,4 & 0 & 40,0 & 1,2 & 0 \\
\hline encanoamento & 0 & 0 & 0 & 0 & 0 & 0 \\
\hline encurvamento & 0 & 13,1 & 14,3 & 28,0 & 15,5 & 21,4 \\
\hline arqueamento & 0 & 65,5 & 51,4 & 0 & 69,0 & 57,0 \\
\hline rach. superficial & 0 & 23,8 & 15,7 & 36,0 & 14,3 & 25,7 \\
\hline rach. de topo & 0 & 63,1 & 55,7 & 28,0 & 61,9 & 74,3 \\
\hline rach. interna & 0 & 0 & 0 & 0 & 0 & 0 \\
\hline colapso & 0 & 2,4 & 4,3 & 64 & 3,6 & 5,7 \\
\hline tensões & 0 & 0 & 0 & 69 & 10 & 40 \\
\hline
\end{tabular}

* condições descritas na Tabela 17 
Conforme pode ser observado, a pré-secagem favoreceu na redução dos defeitos, mesmo empregando programas mais drásticos. No caso das condições 2 e 3 , verifica-se que a adoção de um programa mais drástico implicou em redução do padrão de qualidade da madeira seca, pelo aumento na incidência do arqueamento e das rachaduras de topo. Contudo, a pré-secagem reduziu a incidência do colapso.

Considerando a duração da secagem e a qualidade final da madeira, foi recomendado pelos autores a adoção do programa de secagem que emprega as condições 2 , mesmo para madeiras com alta umidade inicial.

A Tabela 19 mostra os parâmetros de programas de secagem sugeridos ou empregados por diversos autores, através de diferentes metodologias, e também por experiência prática, comparados aos resultados obtidos na presente pesquisa. 
Tabela 19. Programas de secagem para Eucalipto grandis.

\begin{tabular}{cccc}
\hline $\begin{array}{c}\text { TEMPERATURA } \\
\text { INICIAL }\left({ }^{\circ} \mathbf{C}\right)\end{array}$ & $\begin{array}{c}\text { TEMPERATURA } \\
\text { FINAL }\left({ }^{\circ} \mathbf{C}\right)\end{array}$ & $\begin{array}{c}\text { POTENCIAL } \\
\text { DE SECAGEM }\end{array}$ & FONTE \\
\hline $\mathbf{4 2}$ & $\mathbf{6 6}$ & $\mathbf{2 , 2 0}$ & presente pesquisa \\
38 & 66 & $(2,50$ até 4,90$)$ & FPL $(1998)$ \\
40 & 60 & $2,00 \pm 0,30$ & Xylema $^{5}$ \\
40 & 60 & $(2,10$ até 3,50$)$ & Pratt (1974) \\
40 & 65 & 2,00 & Ciniglio $(1998)$ \\
40 & 70 & 2,50 & Jankowsky ${ }^{8}$ et al. \\
44 & 64 & - & Mendoza (1995) \\
45 & 60 & $(2,30$ até 3,20) & Northway (1996) \\
45 & 70 & $(2,90$ até 4,30$)$ & Campbell ${ }^{9}$ \\
49 & 82 & 3,47 & Simpson \& Verrill (1997) \\
50 & 70 & - & Northway (1996) \\
50 & 70 & $(1,54-3,57)$ & Martins et al (1999) \\
55 & 85 & - & Stohr (1984) \\
\hline
\end{tabular}

* citado por Northway (1996)

Conforme pode ser observado, os paràmetros indicados no presente trabalho mostram segurança, estando dentro da faixa dos programas que empregam condições de secagem mais suaves, e concordantes com Campbell \& Hartley (1988), Jankowsky (1995), Vermaas (1995), dentre outros, que recomendam a utilização de temperaturas iniciais inferiores à $45^{\circ} \mathrm{C}$.

Comparando-se com os programas obtidos por experiência prática, como os recomendados por Xylema ${ }^{5}$, FPL (1998) e Jankowsky ${ }^{8}$ et al., percebe-se que os valores estão bem aproximados, reforçando a adequação da metodologia.

\footnotetext{
"CAMPBELL, G. S. Index of kiln drying schedules for timbers dried in Australia. Melbourne: Csiro, Division of Building Research, 1980.
} 
Ciniglio (1998) empregou a mesma metodologia para indicação de programas adotada neste trabalho. Observa-se que os valores são bastante similares, apesar das madeiras possuírem origens diferentes. Isto induz que o programa indicado pode ser recomendado para qualquer madeira de Eucalipto grandis, não importando a procedência.

Stohr (1984) e Northway (1996), usando temperaturas mais elevadas, obtiveram resultados satisfatórios na secagem de Eucalipto grandis. Entretanto, a secagem empregou vaporizações periódicas que contribuem para evitar os defeitos. Northway (1996) frisa que empregou o programa sugerido por Stohr (1984) e considerou as condições iniciais de secagem muito severas, pois não obteve bons resultados, com ocorrência de fortes rachaduras superficiais.

Os parâmetros indicados através da massa específica básica, de acordo com o trabalho de Simpson \& Verrill (1997), são bastante elevados e não são indicados para secagem de Eucalipto grandis com alta umidade. Conforme os próprios autores salientaram, existem madeiras que não respondem positivamente à esta metodologia para estimar programas de secagem.

Com base nos resultados obtidos e nas informações da literatura, pode-se concluir que para secagem convencional da madeira de Eucalipto grandis, o programa indicado (Tabela 21 - Anexo A) é adequado e sua aplicação resultará em madeira seca com pequena incidência de defeitos.

Para que possam ser usados programas mais agressivos, que reduzirão o tempo de secagem, recomenda-se que a madeira seja submetida a uma pré-secagem anterior à secagem convencional. 


\section{CONCLUSÕeS}

Com base na discussão dos resultados obtidos, pode-se concluir que:

- os resultados do ensaio a $100^{\circ} \mathrm{C}$ possibilitaram a indicação dos programas de secagem especificos para as madeiras de Imbuia, Itaúba, Mandioqueira, PerobaMica e Pinus hondurensis; e grupar as madeiras de Eucalipto grandis, Eucalipto tereticornis, Freijó, Jatobá, Jutaí-Cica, Pau-Marfim, Tamboril e Tauari em dois programas básicos;

- tanto a aplicação dos programas de secagem em laboratório (com exceção para a madeira de Imbuia) como a comparação com as informações disponíveis em literatura confirmaram a adequação da metodologia utilizada para a indicação dos programas de secagem;

- é possivel grupar espécies em um mesmo programa de secagem, entretanto características especificas como o teor de umidade inicial, a velocidade de secagem e a tendência aos defeitos devem ser considerados durante a secagem conjunta;

- a massa específica básica, isoladamente, não é um bom parâmetro para indicação de programas de secagem e grupamento de espécies;

- para espécies com acentuada propensão a apresentar defeitos e alto teor de umidade inicial, é indicado efetuar a pré-secagem antes do processo de secagem convencional. 
ANEXO A

Programas de secagem propostos 
Tabela 20. Programa de secagem proposto para as madeiras de Eucalipto tereticornis, Freijó, Jatobá e Jutaí-Cica com até $28 \mathrm{~mm}$ de espessura.

\begin{tabular}{cccccc}
\hline $\begin{array}{c}\text { Umidade da } \\
\text { madeira }(\mathbf{\%})\end{array}$ & $\begin{array}{c}\text { Ts } \\
\left({ }^{\circ} \mathbf{C}\right)\end{array}$ & $\begin{array}{c}\text { Tu } \\
\left({ }^{\circ} \mathbf{C}\right)\end{array}$ & $\begin{array}{c}\text { UR } \\
(\mathbf{\%})\end{array}$ & $\begin{array}{c}\text { UE } \\
(\mathbf{\%})\end{array}$ & $\begin{array}{c}\text { Potencial } \\
\text { de secagem }\end{array}$ \\
\hline aquecimento & 40,0 & 39,0 & 94 & 21,6 & - \\
\hline até 50 & 40,0 & 38,5 & 91 & 19,8 & - \\
\hline $\mathbf{5 0}$ & 40,0 & 38,0 & 88 & 18,3 & 2,73 \\
\hline $\mathbf{4 0}$ & 40,0 & 37,5 & 85 & 17,0 & 2,35 \\
\hline $\mathbf{3 0}$ & 40,0 & 36,5 & 80 & 15,1 & 1,99 \\
\hline $\mathbf{2 5}$ & 47,0 & 41,5 & 69 & 12,0 & 2,08 \\
\hline $\mathbf{2 0}$ & 54,0 & 46,5 & 64 & 10,0 & 2,00 \\
\hline $\mathbf{1 5}$ & 60,0 & 48,5 & 52 & 7,6 & 1,97 \\
\hline $\mathbf{1 0}$ & 60,0 & 41,0 & 31 & 4,9 & 2,05 \\
\hline $\mathbf{5}$ & 60,0 & 32,0 & 13 & 2,6 & 1,92 \\
\hline
\end{tabular}

Tabela 21. Programa de secagem proposto para as madeiras de Eucalipto grandis, Pau-Marfim, Tamboril e Tauari com até $28 \mathrm{~mm}$ de espessura.

\begin{tabular}{cccccc}
\hline $\begin{array}{c}\text { Umidade da } \\
\text { madeira }(\mathbf{\%})\end{array}$ & $\begin{array}{c}\text { Ts } \\
\left({ }^{\circ} \mathbf{C}\right)\end{array}$ & $\begin{array}{c}\mathbf{T u} \\
\left({ }^{\circ} \mathbf{C}\right)\end{array}$ & $\begin{array}{c}\text { UR } \\
\mathbf{( \% )}\end{array}$ & $\begin{array}{c}\text { UE } \\
(\mathbf{\%})\end{array}$ & $\begin{array}{c}\text { Potencial } \\
\text { de secagem }\end{array}$ \\
\hline aquecimento & 40,0 & 39,0 & 94 & 21,6 & - \\
\hline até 50 & 40,0 & 38,0 & 88 & 18,3 & - \\
\hline $\mathbf{5 0}$ & 40,0 & 37,5 & 85 & $17, \boldsymbol{\bullet}$ & 2,94 \\
\hline $\mathbf{4 0}$ & 40,0 & 36,5 & 80 & 15,1 & 2,65 \\
\hline $\mathbf{3 0}$ & 40,0 & 36,0 & 77 & 14,1 & 2,12 \\
\hline $\mathbf{2 5}$ & 48,0 & 42,0 & 69 & 11,5 & 2,17 \\
\hline $\mathbf{2 0}$ & 56,0 & 48,0 & 62 & 9,5 & 2,11 \\
\hline $\mathbf{1 5}$ & 65,0 & 52,0 & 50 & 7,0 & 2,14 \\
\hline $\mathbf{1 0}$ & 65,0 & 44,0 & 31 & 4,7 & 2,13 \\
\hline $\mathbf{5}$ & 65,0 & 34,0 & 12 & 2,4 & 2,08 \\
\hline
\end{tabular}


Tabela 22. Programa de secagem proposto para madeira de Imbuia com até $28 \mathrm{~mm}$ de espessura.

\begin{tabular}{cccccc}
\hline $\begin{array}{c}\text { Umidade da } \\
\text { madeira }(\%)\end{array}$ & $\begin{array}{c}\text { Ts } \\
\left({ }^{\circ} \mathbf{C}\right)\end{array}$ & $\begin{array}{c}\text { Tu } \\
\left({ }^{\circ} \mathbf{C}\right)\end{array}$ & $\begin{array}{c}\text { UR } \\
(\mathbf{\%})\end{array}$ & $\begin{array}{c}\text { UE } \\
(\mathbf{\%})\end{array}$ & $\begin{array}{c}\text { Potencial } \\
\text { de secagem }\end{array}$ \\
\hline aquecimento & 40,0 & 39,0 & 94 & 21,6 & - \\
\hline até 50 & 40,0 & 38,5 & 91 & 19,8 & - \\
\hline $\mathbf{5 0}$ & 40,0 & 38,0 & 88 & 18,3 & 2,73 \\
\hline $\mathbf{4 0}$ & 40,0 & 37,5 & 85 & 17,0 & 2,35 \\
\hline $\mathbf{3 0}$ & 40,0 & 36,5 & 80 & 15,1 & 1,99 \\
\hline $\mathbf{2 5}$ & 50,0 & 45,0 & 74 & 12,6 & 1,98 \\
\hline $\mathbf{2 0}$ & 60,0 & 53,0 & 67 & 10,2 & 1,96 \\
\hline $\mathbf{1 5}$ & 70,0 & 58,0 & 56 & 7,6 & 1,97 \\
\hline $\mathbf{1 0}$ & 70,0 & 50,0 & 35 & 5,0 & 2,00 \\
\hline $\mathbf{5}$ & 70,0 & 41,0 & 18 & 3,1 & 1,94 \\
\hline
\end{tabular}

Tabela 23. Programa de secagem proposto para a madeira de Peroba-Mica com até $28 \mathrm{~mm}$ de espessura.

\begin{tabular}{cccccc}
\hline $\begin{array}{c}\text { Umidade da } \\
\text { madeira }(\mathbf{\%})\end{array}$ & $\begin{array}{c}\text { Ts } \\
\left({ }^{\circ} \mathbf{C}\right)\end{array}$ & $\begin{array}{c}\text { Tu } \\
\left({ }^{\circ} \mathbf{C}\right)\end{array}$ & $\begin{array}{c}\text { UR } \\
(\mathbf{\%})\end{array}$ & $\begin{array}{c}\text { UE } \\
(\%)\end{array}$ & $\begin{array}{c}\text { Potencial } \\
\text { de secagem }\end{array}$ \\
\hline aquecimento & 40,0 & 39,0 & 94 & 21,6 & - \\
\hline Até 50 & 40,0 & 38,5 & 91 & 19,8 & - \\
\hline $\mathbf{5 0}$ & 40,0 & 37,5 & 85 & 17,0 & 2,94 \\
\hline $\mathbf{4 0}$ & 40,0 & 36,5 & 80 & 15,1 & 2,65 \\
\hline $\mathbf{3 0}$ & 40,0 & 35,0 & 72 & 12,8 & 2,34 \\
\hline $\mathbf{2 5}$ & 50,0 & 43,0 & 65 & 10,5 & 2,38 \\
\hline $\mathbf{2 0}$ & 60,0 & 50,5 & 58 & 8,5 & 2,35 \\
\hline $\mathbf{1 5}$ & 70,0 & 55,0 & 48 & 6,5 & 2,31 \\
\hline $\mathbf{1 0}$ & 70,0 & 47,0 & 29 & 4,3 & 2,33 \\
\hline $\mathbf{5}$ & 70,0 & 37,0 & 13 & 2,0 & 2,50 \\
\hline
\end{tabular}


Tabela 24. Programa de secagem proposto para a madeira de Mandioqueira com até $28 \mathrm{~mm}$ de espessura.

\begin{tabular}{cccccc}
\hline $\begin{array}{c}\text { Umidade da } \\
\text { madeira (\%) }\end{array}$ & $\begin{array}{c}\text { Ts } \\
\left({ }^{\circ} \mathbf{C}\right)\end{array}$ & $\begin{array}{c}\text { Tu } \\
\left({ }^{\circ} \mathbf{C}\right)\end{array}$ & $\begin{array}{c}\text { UR } \\
(\mathbf{\%})\end{array}$ & $\begin{array}{c}\text { UE } \\
\mathbf{( \% )}\end{array}$ & $\begin{array}{r}\text { Potencial } \\
\text { de secagem }\end{array}$ \\
\hline aquecimento & 45,0 & 44,0 & 94 & 21,2 & - \\
\hline até 50 & 45,0 & 43,0 & 89 & 18,4 & - \\
\hline $\mathbf{5 0}$ & 45,0 & 42,0 & 84 & 16,2 & 3,08 \\
\hline $\mathbf{4 0}$ & 45,0 & 41,0 & 79 & 14,2 & 2,81 \\
\hline $\mathbf{3 0}$ & 45,0 & 39,0 & 68 & 11,5 & 2,61 \\
\hline $\mathbf{2 5}$ & 52,0 & 44,0 & 61 & 9,5 & 2,63 \\
\hline $\mathbf{2 0}$ & 61,0 & 50,0 & 54 & 7,7 & 2,60 \\
\hline $\mathbf{1 5}$ & 70,0 & 53,0 & 42 & 5,7 & 2,63 \\
\hline $\mathbf{1 0}$ & 70,0 & 45,0 & 25 & 3,8 & 2,63 \\
\hline $\mathbf{5}$ & 70,0 & 37,0 & 13 & 2,0 & 2,50 \\
\hline
\end{tabular}

Tabela 25. Programa de secagem proposto para a madeira de Itaúba com até $28 \mathrm{~mm}$ de espessura.

\begin{tabular}{cccccc}
\hline $\begin{array}{c}\text { Umidade da } \\
\text { madeira (\%) }\end{array}$ & $\begin{array}{c}\text { Ts } \\
\left({ }^{\circ} \mathbf{C}\right)\end{array}$ & $\begin{array}{c}\text { Tu } \\
\left({ }^{\circ} \mathbf{C}\right)\end{array}$ & $\begin{array}{c}\text { UR } \\
(\mathbf{\%})\end{array}$ & $\begin{array}{c}\text { UE } \\
(\mathbf{\%})\end{array}$ & $\begin{array}{c}\text { Potencial } \\
\text { de secagem }\end{array}$ \\
\hline aquecimento & 45,0 & 44,0 & 94 & 21,2 & - \\
\hline até 50 & 45,0 & 43,5 & 91 & 19,4 & - \\
\hline $\mathbf{5 0}$ & 45,0 & 43,0 & 89 & 18,4 & 2,72 \\
\hline $\mathbf{4 0}$ & 45,0 & 42,5 & 86 & 17,0 & 2,35 \\
\hline $\mathbf{3 0}$ & 45,0 & 41,5 & 81 & 15,1 & 1,99 \\
\hline $\mathbf{2 5}$ & 52,0 & 47,0 & 74 & 12,4 & 2,02 \\
\hline $\mathbf{2 0}$ & 61,0 & 54,0 & 67 & 10,1 & 1,98 \\
\hline $\mathbf{1 5}$ & 70,0 & 57,5 & 54 & 7,3 & 2,05 \\
\hline $\mathbf{1 0}$ & 70,0 & 50,0 & 35 & 5,0 & 2,00 \\
\hline $\mathbf{5}$ & 70,0 & 38,0 & 15 & 2,4 & 2,08 \\
\hline
\end{tabular}


Tabela 26. Programa de secagem proposto para madeira de Pinus hondurensis com até $28 \mathrm{~mm}$ de espessura.

\begin{tabular}{cccccc}
\hline $\begin{array}{c}\text { Umidade da } \\
\text { madeira }(\mathbf{\%})\end{array}$ & $\begin{array}{c}\text { Ts } \\
\left({ }^{\circ} \mathbf{C}\right)\end{array}$ & $\begin{array}{c}\text { Tu } \\
\left({ }^{\circ} \mathbf{C}\right)\end{array}$ & $\begin{array}{c}\text { UR } \\
(\mathbf{\%})\end{array}$ & $\begin{array}{c}\text { UE } \\
(\mathbf{\%})\end{array}$ & $\begin{array}{c}\text { Potencial } \\
\text { de secagem }\end{array}$ \\
\hline aquecimento & 55,0 & 54,0 & 95 & 21,0 & - \\
\hline até 50 & 55,0 & 51,5 & 82 & 14,6 & - \\
\hline $\mathbf{5 0}$ & 55,0 & 50,5 & 82 & 13,0 & 3,84 \\
\hline $\mathbf{4 0}$ & 55,0 & 48,0 & 66 & 10,3 & 3,88 \\
\hline $\mathbf{3 0}$ & 55,0 & 45,5 & 56 & 8,5 & 3,52 \\
\hline $\mathbf{2 5}$ & 63,0 & 51,0 & 51 & 7,3 & 3,42 \\
\hline $\mathbf{2 0}$ & 71,0 & 54,0 & 42 & 5,7 & 3,51 \\
\hline $\mathbf{1 5}$ & 80,0 & 56,0 & 32 & 4,2 & 3,57 \\
\hline $\mathbf{1 0}$ & 80,0 & 50,0 & 22 & 2,9 & 3,45 \\
\hline $\mathbf{5}$ & 80,0 & 41,0 & 11 & 1,5 & 3,33 \\
\hline
\end{tabular}

Nas Tabelas 20 a 26;

$\mathrm{Ts}=$ Temperatura de bulbo seco $\quad \mathrm{UR}=$ Umidade relativa do ar

$\mathrm{Tu}=$ Temperatura de bulbo úmido $\mathrm{UE}=$ Umidade de equilibrio 


\section{REFERÊNCIAS BIBLIOGRÁFICAS}

BAKER, W.J. How wood dries. Madison: Forest Products Laboratory, 1956. 9p. (Report, 1642).

BANGI, A.P.; BELLO, E.D.; BRAMHALL, G. A technique for calculating kilnschedule modifications to reduce kiln-drying time of some philippine lumber species. Forest Products Research Development Institute Journal, v.20, n. 1/2, p. 57-65, Jan./June 1991.

BARRICHELLO, L.E.G. Densidade básica: subsídios para determinação ( $1^{a}$ parte). Piracicaba: ESALQ, Departamento de Silvicultura, 1983. 6p. (Informações SQCE, 3)

BENNETT, C.O.; MYERS, J.E. Fenômenos de transporte: Quantidade de movimento, calor e massa. Trad. de E.W. Leser. São Paulo: McGraw-Hill do Brasil, 1978. 812p.

BOONE, R.S.; KOZLIK, C.J.; BOIS, P.J.; WENGERT, E.M. Dry kiln schedules for commercial woods: temperate and tropical. Madison: USDA, Forest Service, Forest Products Laboratory, 1988. 158p.

BRANDÃO, A.T.O. Determinação de metodologia para a indicação de programas de secagem de madeiras. Piracicaba, 1989. 100p. Dissertação (Mestrado) - Escola Superior de Agricultura "Luiz de Queiroz", Universidade de São Paulo. 
BRANDÃO, A.T.O.; JANKOWSKY, I.P. A screening to select kiln schedules. IPEF international, n. 2, p. 20-24, 1992.

BRASIL. Instituto Brasileiro de Desenvolvimento Florestal. Madeiras da Amazônia: características e utilização - Floresta Nacional do Tapajós. Brasilia: IBDF, 1981. V.1, $113 p$.

BRASIL. Instituto Brasileiro de Desenvolvimento Florestal. Madeiras da Amazônia: características e utilização - Estação experimental de Curuá-una. Brasilia: IBDF, 1988. V. 2, 236p.

BROTERO, P.A. Secagem de madeiras em estufa. São Paulo: IPT, 1941. 47p.

BROWN, H.P.; PANSHIN, A.J.; FORSAITH, C.C. Textbook of wood technology. New York: McGraw-Hill, 1949. 652p.

BURGER, L.M.; RICHTER, H.G. Anatomia da madeira. São Paulo: Nobel, 1991. $154 \mathrm{p}$.

CAMPBELL, G.S.; HARTLEY, J. Drying and dried wood. In: HILliS, W. E. ; BROWN, A.G. Eucalypts for wood production. Melbourne: Academic Press, 1988. cap. 16 , p. $328-336$.

CAVALCANTE, A.de A. Ocorrência do colapso na secagem da madeira de Eucalyptus grandis e Eucalyptus saligna. Piracicaba, 1991. 76p. Dissertação (Mestrado) Escola Superior de Agricultura "Luiz de Queiroz", Universidade de São Paulo. 
CINIGLIO, G. Avaliação da secagem de madeira serrada de E. grandis e E. urophylla. Piracicaba, 1998. 69p. Dissertação (Mestrado) - Escola Superior de Agricultura "Luiz de Queiroz", Universidade de São Paulo.

DENIG, J. Kiln schedule development, use, and modification. In: FOREST PRODUCTS SOCIETY. Profitable solutions for quality drying of softwoods and hardwoods. Charlotte, 1994. p. 71-75.

DURAND, P.Y. Contribution à l'étude de la déterminacion des tables de séchage à partir des caractères physiques du bois. Revue Bois et Forêts des Tropiques, n. 207, p. 63-78, 1985.

FPL - Forest Products Laboratory. FPL Statistics Group - WWW Hardwood Drying Schedules. http://wwwl.fpl.fs.fed.us/drying.html (Oct., 1998).

GALVÃO, A.P.M. Secagem acelerada: Programa para a madeira de Jatobá (Hymenea stilbocarpa Hayne). IPEF, n.12, p. 151-161, Jun. 1976.

GALVÃO, A.P.M.; JANKOWSKY, I.P. Secagem racional da madeira. São Paulo: Nobel, 1985. 111p.

HART, C.A. The drying of wood. Raleigh: North Caroline Agricultural Extension Service, 1965. 24p. (Extension Circular, 471).

HILDEBRAND, R. Kiln drying of sawn timber. Berlin: Maschinenbau GmbH, 1970. $198 \mathrm{p}$. 
INSTITUTO DE PESQUISAS TECNOLÓGICAS. Divisão de Madeiras. Madeira: o que é e como pode ser processada e utilizada. São Paulo: ABPM, 1985. 189p. (Boletim ABPM, 36).

JANKOWSKY, I.P. Potencialidade do creosoto de Eucalyptus spp como preservativo para madeiras. São Paulo, 1986. 159p. Tese (Doutorado) - Escola Politécnica, Universidade de São Paulo.

JANKOWSKY, I.P. Equipamentos e processos para secagem de madeiras. In: SEMINÁRIO INTERNACIONAL DE UTRIZAÇÃO DE MADEIRA DE EUCALIPTO PARA SERRARIA, 1., São Paulo, 1995. Anais. São Paulo: IPEF;IPT, 1995. p. 109-118.

KOLLMANN, F.F.P.; CÔTÉ, W.A. Principles of wood science and technology. Berlin: Springer-Verlag, 1968. 592p.

LEPAGE, E.S.; GERALDO, F.C.; ZANOTTO, P.A.; MILANO, S. Métodos de tratamento. In: LEPAGE, E.S. (Coord.) Manual de preservação de madeiras. São Paulo: Instituto de Pesquisas Tecnológicas do Estado de São Paulo, 1986. cap. VII, p.343-419.

LITTLE, R.L.; TOENNISSON, R.L Drying hardwood lumber using computer controlled mini-step schedules. In: UPGRADING WOOD QUALITY THROUGH DRYING TECHNOLOGY, Tacoma, 1989. Proceedings. Tacoma: IUFRO, 1989. p. 203-212.

MAINIERI, C.; CHIMELO, J.P. Fichas de características das madeiras brasileiras. São Paulo: IPT;DIMAD, 1989. 418p. 
MARTINS, V.A. Secagem de madeiras ao ar livre na região do Distrito Federal. Brasília: IBDF, 1986. 18p. (IBDF - Série Técnica, 14).

MARTINS, V.A. Secagem de madeira serrada. Brasília: IBDF, 1988. 56p.

MARTINS, V.A.; MARQUES, M.H.B.; MENDES, A.S. Madeiras da Amazônia de secagem rápida. Madeira \& Tecnologia, n.7, p.44-50, Nov/Dez. 1997.

MARTINS, V.A.; GOUVEIA, F.N.; MARTINEZ, S. Secagem convencional de madeira de Eucalipto. In: CONGRESSO INTERNACIONAL SOBRE ECOSSISTEMAS FLORESTAIS, 5., Curitiba, 1999. Anais. Curitiba: Biosfera, 1999. (Poster)

McMILLEN, J.M. Accelerated kiln drying of presurfaced 1-inch Northern Red Oak. Madison: USDA, Forest Service, 1969. 29p. (Research Paper - FPL, 122).

MENDES, A.S.; MARTINS, V.A.; MARQUES, M.H.B. Programas de secagem para madeiras brasileiras. Brasília: IBAMA, 1998. 114p.

MENDES, A.S.; SIMPSON, W.T.;VERRILL, S.P. Laboratory test for grouping tropical species for kiln drying. Wood Science and Technology, v.29, p. 353-362. 1995.

MENDOZA, I.E.L. Experiencia chilena en la utilizacion del Eucalipto. In: SEMINÁRIO INTERNACIONAL DE UTLLIZAÇÃO DE MADEIRA DE EUCALIPTO PARA SERRARIA, 1., São Paulo, 1995. Anais. São Paulo: IPEF;IPT, 1995. p.92-108.

NORTHWAY, R.L. Drying strategies for plantation-grow Eucalypts. In: INTERNATIONAL IUFRO WOOD DRYING CONFERENCE, 5. Quebec, 1996. Proceedings. Quebec: IUFRO, 1996. p.289-296. 
OLIVEIRA, L.C.S. Perguntas e respostas em secagem de madeiras. São Paulo: IPT, 1981. 36p.

PERELYGIN, L.M. Science of wood. Moscow: Higher School Publishing House, 1965. 200p.

PONCE, R.M.; WATAI, L.T. Manual de secagem de madeira. Brasília: MIC;STI;IPT, 1985. 70p. (Série Documentos, 22).

PRATT, G.H. Timber drying manual. London: Department of the Environment/Building Research Establishment, 1974. 152p.

RASMUSSEN, E.F. Dry kiln operator's manual. Madison: USDA,-Forest Service, 1968. $197 \mathrm{p}$.

SIAU, J.F. Flow in wood. New York: Syracuse University Press, 1971. $131 \mathrm{p}$.

SIAU, J.F. Transport processes in wood. Berlin: Springer-Verlag, 1984. 245p.

SIMPSON, W.T.; BAAH, C.K. Grouping Tropical wood species for kiln drying. Madison: USDA, Forest Service, Forest Products Laboratory, 1989. 14p.

SIMPSON, W.T.; VERRIL, S.P. Estimating kiln schedules for tropical and temperate hardwoods using specific gravity. Forest Products Journal, v.47, n.7/8, p. 64-68, July/Aug. 1997.

SKAAR, C. Wood-water relations. Berlin: Springer-Veriag, 1988. 263p. 
STCP-ENGENHARIA DE PROJETOS Ltda. Secagem de madeiras serradas. Curitiba: 1990. 68p.

STOHR, H.P. Drying of Eucalyptus grandis: A new approach with HH orientated schedules. In: NORTH AMERICAN WOOD DRYING SYMPOSIUM, Mississippi, 1984. Proceedings. Mississippi State: Mississippi Forest Products Utilization Laboratory, 1984. p. $72-77$.

TOENNISSON, R.L.; LITTLE, R.L. Continuously changing hardwood drying schedules. In: FOREST PRODUCTS SOCIETY. Profitable solutions for quality drying of softwoods and hardwoods. Charlotte, 1994. p. 76-83.

TOMASELLI, I. Secagem de madeira. Curitiba: FUPEF, 1980. 29p.

VERMAAS, H.F. Drying Eucalipts for quality: Material characteristics, pre-drying treatments, drying methods, schedules and optimization of drying quality. In: SEMINÁRIO INTERNACIONAL DE UTILIZAÇÃO DE MADEIRA DE EUCALIPTO PARA SERRARIA, 1., São Paulo, 1995. Anais. São Paulo: IPEF;IPT, 1995. p.119-132.

WENGERT, G.; DENIG, J. Lumber drying: today and tomorrow. Forest Products Journal, v.45, n.5, p. 23-30, May. 1995. 


\section{APÊNDICE 1}

Resultados médios do ensaio a $100^{\circ} \mathrm{C}$ 
Tabela 27. Valores médios do teor de umidade inicial, da massa específica básica e das variáveis dos ensaios a $100^{\circ} \mathrm{C}$.

\begin{tabular}{|c|c|c|c|c|c|c|c|c|c|c|c|c|c|c|c|c|}
\hline ESPÉCIES & $\begin{array}{c}\text { Ui } \\
(\%)\end{array}$ & $\underset{\left(\mathrm{g} / \mathrm{cm}^{3}\right)}{\mathbf{m e}^{3}}$ & $\begin{array}{c}\text { M1 } \\
\text { (g) }\end{array}$ & $\begin{array}{c}\text { M3 } \\
\text { (g) }\end{array}$ & $\begin{array}{l}\text { M5 } \\
(\mathrm{g})\end{array}$ & $\begin{array}{l}\text { T1 } \\
(\mathrm{h})\end{array}$ & $\begin{array}{l}12 \\
(\mathrm{~h})\end{array}$ & $\begin{array}{l}13 \\
(\mathrm{~h})\end{array}$ & $\begin{array}{c}V 1 \\
\left(\mathrm{~g} / \mathrm{cm}^{2} \cdot \mathrm{h}\right)\end{array}$ & $\begin{array}{c}\mathbf{V} \\
\left(\mathrm{g} / \mathrm{cm}^{2} \cdot \mathrm{h}\right)\end{array}$ & $\begin{array}{c}\mathrm{V} 3 \\
\left(\mathrm{~g} / \mathrm{cm}^{2} \mathrm{~h}\right)\end{array}$ & $\begin{array}{c}\mathbf{R 1} \\
\left(\mathrm{U}_{\mathbf{n}}\right)\end{array}$ & $\begin{array}{c}\mathbf{R 2} \\
(\mathbf{U n})\end{array}$ & $\begin{array}{c}\mathbf{R 3} \\
(\mathrm{Un}) \\
\end{array}$ & $\begin{array}{c}\mathbf{R I} \\
\left(\mathbf{U}_{n}\right)\end{array}$ & $\begin{array}{c}\mathbf{C} \\
(\mathrm{Un})\end{array}$ \\
\hline E. grandis & 84,48 & 0,54 & 25,05 & 9,16 & 1,53 & 12,78 & 4,41 & 8,37 & 0,019 & 0,036 & 0,009 & 1,33 & 1,29 & 1,33 & 1,00 & 3,67 \\
\hline E. tereticornis & 48,35 & 0,80 & 20,80 & 12,95 & 2,16 & 17,94 & 2,84 & 15,11 & 0,011 & 0,028 & 0,007 & 2,25 & 2,25 & 2,21 & 1,00 & 2,75 \\
\hline Freijó & 49,47 & 0,56 & 14,35 & 8,74 & $1, \overline{46}$ & 10,77 & 1,93 & 8,84 & 0,012 & 0,030 & 0,008 & 1,17 & 1,17 & 1,08 & 1,00 & 1,54 \\
\hline Imbuia & 97,25 & 0,55 & 30,50 & 9,42 & 1,57 & 26,70 & 9,56 & 17,14 & 0,011 & 0,024 & 0,005 & 1,13 & 1,13 & 1,00 & 1,96 & 3,71 \\
\hline Itaúba & 67,82 & 0,69 & 26,50 & 11,76 & 1,96 & 29,85 & 8,96 & 20,88 & 0,009 & 0,017 & 0,005 & 3,00 & 3,00 & 2,63 & 1,00 & 2,50 \\
\hline Jatoba & 48,58 & 0,86 & 20,56 & 12,80 & $2, \overline{13}$ & 16,54 & $2,5 \overline{3}$ & 14,01 & 0,012 & 0,034 & 0,008 & 2,25 & 2,13 & 2,21 & 1,00 & 2,00 \\
\hline Jutaí-Cica & 52,59 & 0,78 & 22,81 & 13,03 & 2,17 & 12,36 & 2,47 & 9,89 & 0,017 & 0,040 & 0,011 & 1,00 & 1,00 & 1,00 & 1,00 & 1,46 \\
\hline Mandioqueira & 68,87 & 0,65 & 25,36 & 11,06 & 1,84 & 7,99 & 2,68 & 5,31 & 0,030 & 0,054 & 0,018 & 2,75 & 2,63 & 2,71 & 1,00 & 1,83 \\
\hline Pau-Marfim & 35,38 & 0,65 & 20,33 & 10,60 & $1, \overline{77}$ & 10,56 & 2,27 & 8,28 & 0,018 & 0,043 & 0,011 & 1,75 & 1,75 & 1,63 & 1,00 & 2,79 \\
\hline Peroba-Mica & 70,65 & 0,60 & 22,59 & 9,62 & 1,60 & 9,68 & 2,91 & 6,77 & 0,022 & 0,045 & 0,012 & 2,50 & 2,08 & 2,04 & 1,00 & 1,46 \\
\hline P. hondurensis & 162,71 & 0,41 & 33,69 & 6,27 & 1,04 & 6,66 & 3,54 & 3,13 & 0,049 & 0,079 & 0,017 & 2,75 & 2,75 & 2,67 & 1,00 & 2,33 \\
\hline Tamboril & 77,82 & 0,41 & 16,83 & 6,50 & 1,08 & 8,31 & 2,99 & 5,32 & 0,019 & 0,035 & 0,010 & 1,00 & 1,00 & 1,00 & 1,00 & 2,38 \\
\hline Tauari & 59,63 & 0,59 & 17,66 & 8,89 & 1,48 & 8,76 & 2,45 & 6,31 & 0,019 & 0,034 & 0,013 & 2,17 & 2,17 & 1,63 & 1,00 & 1,79 \\
\hline \multicolumn{5}{|c|}{ Onde: $\begin{array}{ll} & \mathbf{U} \mathbf{i}=\text { Umidade inicial } \\
& \mathbf{m e}_{\mathrm{b}}=\text { Massa específica básica } \\
& \mathbf{M 1}=\text { massa inicial de água } \\
\mathbf{M} 3=\text { massa de água até } 30 \% \\
\mathbf{M 5}=\text { massa de água até } 5 \%\end{array}$} & $\begin{array}{l}=\text { ten } \\
=\mathrm{vel} \\
=\mathrm{vel} \\
=\mathrm{vel}\end{array}$ & $\begin{array}{l}\text { de sec } \\
\text { dade d } \\
\text { dade d } \\
\text { dade d }\end{array}$ & $\begin{array}{l}\text { sem de } \\
\text { secage } \\
\text { secage }\end{array}$ & $\begin{array}{l}0 \text { até } \\
\text { da } U \\
\text { da } U \\
\text { de } 30\end{array}$ & $\begin{array}{l}\text { té } 5 \% \\
\text { té } 30 \% \\
\text { té } 5 \%\end{array}$ & $\begin{array}{l}\mathbf{R 2} \\
\mathbf{R 3}= \\
\mathbf{R I}= \\
\mathrm{C}=\end{array}$ & $\begin{array}{l}=\text { rachadur } \\
=\text { rachadura } \\
\text { Colapso }\end{array}$ & $\begin{array}{l}\text { as de to } \\
\text { as intern }\end{array}$ & $\begin{array}{l}\text { po de } \\
\text { has }\end{array}$ & 30 até & & \\
\hline
\end{tabular}




\section{APÊNDICE 2}

Amplitude de variação dos resultados obtidos no ensaio a $100^{\circ} \mathrm{C}$ 
Tabela 28. Amplitude de variação (máximo e mínimo) dos resultados obtidos no ensaio a $100^{\circ} \mathrm{C}$.

\begin{tabular}{|c|c|c|c|c|c|c|c|c|}
\hline ESPÉCIES & $\begin{array}{c}\mathbf{U i} \\
(\%)\end{array}$ & $\begin{array}{c}\mathbf{m e}_{\mathbf{b}} \\
\left(\mathrm{g} / \mathbf{c m}^{3}\right)\end{array}$ & $\begin{array}{c}\mathbf{M 1} \\
(\mathrm{g})\end{array}$ & $\begin{array}{c}\mathbf{M 3} \\
(\mathrm{g})\end{array}$ & $\begin{array}{c}\mathbf{M 5} \\
(\mathrm{g})\end{array}$ & $\begin{array}{c}\mathbf{T 1} \\
(\mathrm{h})\end{array}$ & $\begin{array}{c}\text { T2 } \\
(\mathrm{h})\end{array}$ & $\begin{array}{c}\text { T3 } \\
(\mathrm{h})\end{array}$ \\
\hline E. grandis & $117,8-59,1$ & $0,62-0,46$ & $28,69-20,10$ & $11,26-7,17$ & $1,88-1,20$ & $15,35-10,61$ & $5,51-2,79$ & $11,25-5,83$ \\
\hline E. tereticornis & $60,2-44,1$ & $0,84-0,76$ & $24,35-18,92$ & $13,79-11,68$ & $2,30-1,95$ & $21,79-11,54$ & $3,80-1,91$ & $18,66-9,63$ \\
\hline Freijó & $56,6-40,3$ & $0,63-0,48$ & $16,21-12,35$ & $10,70-7,21$ & $1,78-1,20$ & $14,63-7,50$ & $2,71-0,76$ & $12,45-6,07$ \\
\hline Imbuia & $118,6-59,2$ & $0,70-0,50$ & $34,33-17,94$ & $10,23-8,66$ & $1,71-1,44$ & $37,03-15,83$ & $14,00-3,02$ & $23,09-9,10$ \\
\hline Itaúba & $78,5-56,3$ & $0,72-0,66$ & $29,58-21,74$ & $13,21-9,23$ & $2,20-1,54$ & $44,01-18,80$ & $13,55-4,32$ & $30,54-14,48$ \\
\hline Jatoba & $60,7-38,5$ & $1,01-0,77$ & $23,39-18,22$ & $14,20-11,50$ & $2,29-1,92$ & $24,22-9,32$ & $4,57-1,02$ & $22,04-7,24$ \\
\hline Jutaí-Cica & $58,9-43,5$ & $0,87-0,75$ & $24,40-20,28$ & $13,99-12,42$ & $2,33-2,07$ & $15,89-9,31$ & $3,16-1,30$ & $12,73-7,30$ \\
\hline Mandioqueira & $76,8-62,1$ & $0,73-0,61$ & $27,28-23,28$ & $11,63-10,63$ & $1,94-1,77$ & $9,58-6,41$ & $3,29-2,12$ & $6,35-4,18$ \\
\hline Pau-Marfim & $73,1-48,4$ & $0,70-0,59$ & $24,23-17,33$ & $11,44-9,57$ & $1,91-1,60$ & $12,61-8,96$ & $3,33-1,39$ & $10,06-6,74$ \\
\hline Peroba-Mica & $82,2-50,5$ & $0,64-0,56$ & $25,87-16,84$ & $10,09-9,19$ & $1,68-1,53$ & $11,9-7,75$ & $3,79-1,45$ & $7,90-5,77$ \\
\hline P. hondurensis & $202,6-132,4$ & $0,46-0,33$ & $36,01-30,54$ & $7,17-5,27$ & $1,20-0,88$ & $8,11-5,91$ & $4,86-2,85$ & $3,59-2,64$ \\
\hline Tamboril & $95,2-58,8$ & $0,44-0,38$ & $21,18-12,99$ & $7,02-5,93$ & $1,17-0,99$ & $10,25-6,60$ & $3,70-1,99$ & $6,55-4,27$ \\
\hline Tauari & $65,4-54,3$ & $0,63-0,56$ & $19,63-16,75$ & $9,35-8,31$ & $1,56-1,44$ & $11,85-5,81$ & $3,11-1,44$ & $8,74-4,28$ \\
\hline
\end{tabular}

Continuação Tabela 28

\begin{tabular}{|c|c|c|c|c|c|c|c|c|}
\hline ESPÉCIES & $\begin{array}{c}\text { V1 } \\
\left(\mathrm{g} / \mathrm{cm}^{2} . \mathrm{h}\right)\end{array}$ & $\begin{array}{c}\text { V2 } \\
\left(\mathrm{g} / \mathrm{cm}^{2} . \mathrm{h}\right)\end{array}$ & $\begin{array}{c}\mathbf{V 3} \\
\left(\mathrm{g} / \mathrm{cm}^{2} . \mathrm{h}\right)\end{array}$ & $\begin{array}{c}\mathbf{R 1} \\
(\mathrm{Un} .)\end{array}$ & $\begin{array}{c}\mathbf{R 2} \\
(\mathrm{Un} .)\end{array}$ & $\begin{array}{c}\mathbf{R 3} \\
(\mathrm{Un} .)\end{array}$ & $\begin{array}{c}\text { RI } \\
(\mathrm{Un} .)\end{array}$ & $\begin{array}{c}\text { C } \\
(\mathrm{Un} .)\end{array}$ \\
\hline E. grandis & $0,025-0,014$ & $0,044-0,029$ & $0,010-0,006$ & $3,0-1,0$ & $2,0-1,0$ & $3,0-1,0$ & $1,0-1,0$ & $5,0-2,0$ \\
\hline E. tereticornis & $0,015-0,008$ & $0,047-0,019$ & $0,010-0,006$ & $3,0-1,0$ & $3,0-1,0$ & $3,0-1,0$ & $1,0-1,0$ & $4,0-2,0$ \\
\hline Freijó & $0,015-0,01$ & $0,043-0,023$ & $0,010-0,007$ & $3,0-1,0$ & $3,0-1,0$ & $3,0-1,0$ & $1,0-1,0$ & $2,0-1,0$ \\
\hline Imbuia & $0,020-0,008$ & $0,036-0,016$ & $0,008-0,004$ & $3,0-1,0$ & $3,0-1,0$ & $1,0-1,0$ & $4,0-1,0$ & $5,0-1,0$ \\
\hline Itaúba & $0,011-0,005$ & $0,024-0,011$ & $0,007-0,003$ & $3,0-3,0$ & $3,0-3,0$ & $3,0-1,0$ & $1,0-1,0$ & $3,0-2,0$ \\
\hline Jatoba & $0,021-0,007$ & $0,057-0,002$ & $0,013-0,005$ & $3,0-1,0$ & $3,0-1,0$ & $3,0-1,0$ & $1,0-1,0$ & $2,0-2,0$ \\
\hline Jutaí-Cica & $0,023-0,013$ & $0,053-0,032$ & $0,015-0,008$ & $1,0-1,0$ & $1,0-1,0$ & $1,0-1,0$ & $1,0-1,0$ & $3,0-1,0$ \\
\hline Mandioqueira & $0,036-0,026$ & $0,064-0,044$ & $0,023-0,015$ & $3,0-2,0$ & $3,0-2,0$ & $3,0-2,0$ & $1,0-1,0$ & $2,0-1,0$ \\
\hline Pau-Marfim & $0,022-0,014$ & $0,052-0,036$ & $0,012-0,009$ & $3,0-1,0$ & $3,0-1,0$ & $3,0-1,0$ & $1,0-1,0$ & $4,0-1,0$ \\
\hline Peroba-Mica & $0,027-0,017$ & $0,053-0,037$ & $0,014-0,010$ & $3,0-1,0$ & $5,0-1,0$ & $5,0-1,0$ & $1,0-1,0$ & $3,0-1,0$ \\
\hline P. hondurensis & $0,057-0,042$ & $0,090-0,061$ & $0,018-0,015$ & $3,0-2,0$ & $3,0-2,0$ & $3,0-2,0$ & $1,0-1,0$ & $3,0-1,0$ \\
\hline Tamboril & $0,024-0,015$ & $0,046-0,026$ & $0,012-0,008$ & $1,0-1,0$ & $1,0-1,0$ & $1,0-1,0$ & $1,0-1,0$ & $3,0-2,0$ \\
\hline Tauari & $0,026-0,014$ & $0,049-0,028$ & $0,017-0,009$ & $3,0-1,0$ & $3,0-1,0$ & $3,0-1,0$ & $1,0-1,0$ & $2,0-1,0$ \\
\hline
\end{tabular}




\section{APÊNDICE 3}

Programas seguidos nos ensaios de secagem convencional 
Tabela 29. Programa de secagem empregado para a madeira de Freijó.

\begin{tabular}{cccccc}
\hline $\begin{array}{c}\text { Umidade da } \\
\text { madeira (\%) }\end{array}$ & $\begin{array}{c}\text { Ts } \\
\left({ }^{\circ} \mathbf{C}\right)\end{array}$ & $\begin{array}{c}\text { Tu } \\
\left({ }^{\circ} \mathbf{C}\right)\end{array}$ & $\begin{array}{c}\text { UR } \\
(\%)\end{array}$ & $\begin{array}{c}\text { UE } \\
(\%)\end{array}$ & $\begin{array}{c}\text { Potencial } \\
\text { de secagem }\end{array}$ \\
\hline aquecimento & 40,0 & 39,0 & 94 & 21,6 & - \\
\hline até 40 & 40,0 & 39,0 & 94 & 21,6 & - \\
\hline $\mathbf{4 0}$ & 40,0 & 38,5 & 91 & 19,8 & 2,02 \\
\hline $\mathbf{3 5}$ & 40,0 & 37,5 & 85 & 17,0 & 2,06 \\
\hline $\mathbf{3 0}$ & 40,0 & 36,5 & 80 & 15,1 & 1,99 \\
\hline $\mathbf{2 8}$ & 42,0 & 38,0 & 77 & 14,0 & 2,00 \\
\hline $\mathbf{2 6}$ & 45,0 & 40,0 & 73 & 12,8 & 2,03 \\
\hline $\mathbf{2 4}$ & 48,0 & 42,5 & 71 & 11,9 & 2,02 \\
\hline $\mathbf{2 2}$ & 51,0 & 44,5 & 67 & 11,0 & 2,00 \\
\hline $\mathbf{2 0}$ & 54,0 & 46,5 & 64 & 10,0 & 2,00 \\
\hline $\mathbf{1 8}$ & 57,0 & 48,0 & 58 & 8,8 & 2,05 \\
\hline $\mathbf{1 6}$ & 60,0 & 49,5 & 55 & 8,1 & 1,98 \\
\hline $\mathbf{1 4}$ & 60,0 & 47,0 & 47 & 6,9 & 2,03 \\
\hline $\mathbf{1 2}$ & 60,0 & 45,0 & 41 & 6,1 & 1,97 \\
\hline uniformização & 60,0 & 53 & 67 & 10 & - \\
\hline condicionamento & 60,0 & 57,5 & 87 & 16 & - \\
\hline
\end{tabular}

Tabela 30. Programa de secagem empregado para a madeira de Imbuia.

\begin{tabular}{cccccc}
\hline $\begin{array}{c}\text { Umidade da } \\
\text { madeira }(\mathbf{\%})\end{array}$ & $\begin{array}{c}\text { Ts } \\
\left({ }^{\circ} \mathbf{C}\right)\end{array}$ & $\begin{array}{c}\text { Tu } \\
\left({ }^{\circ} \mathbf{C}\right)\end{array}$ & $\begin{array}{c}\text { UR } \\
(\mathbf{\%})\end{array}$ & $\begin{array}{c}\text { UE } \\
(\mathbf{\%})\end{array}$ & $\begin{array}{c}\text { Potencial } \\
\text { de secagem }\end{array}$ \\
\hline aquecimento & 45,0 & 44,0 & 94 & 21,2 & - \\
\hline até 40 & 45,0 & 43,0 & 89 & 18,4 & - \\
\hline $\mathbf{4 0}$ & 45,0 & 42,5 & 86 & 17,0 & 2,36 \\
\hline $\mathbf{3 0}$ & 45,0 & 41,5 & 81 & 15,1 & 1,99 \\
\hline $\mathbf{2 8}$ & 48,0 & 44,0 & 79 & 14,2 & 1,97 \\
\hline $\mathbf{2 6}$ & 51,0 & 46,5 & 76 & 13,2 & 1,97 \\
\hline $\mathbf{2 4}$ & 54,0 & 48,5 & 72 & 11,7 & 2,06 \\
\hline $\mathbf{2 2}$ & 57,0 & 51,0 & 71 & 11,2 & 1,96 \\
\hline $\mathbf{2 0}$ & 60,0 & 53,0 & 67 & 10,2 & 1,96 \\
\hline $\mathbf{1 8}$ & 63,0 & 54,5 & 62 & 9,0 & 2,00 \\
\hline $\mathbf{1 6}$ & 66,0 & 55,0 & 57 & 8,1 & 1,98 \\
\hline $\mathbf{1 4}$ & 70,0 & 57,0 & 53 & 7,1 & 1,98 \\
\hline $\mathbf{1 2}$ & 70,0 & 54,0 & 45 & 6,1 & 1,97 \\
\hline uniformizacão & 70,0 & 62,5 & 70 & 10 & - \\
\hline condicionamento & 70,0 & 67,5 & 88 & 16 & - \\
\hline
\end{tabular}


Tabela 31. Programa de secagem empregado para a madeira de Jutaí-Cica.

\begin{tabular}{cccccc}
\hline $\begin{array}{c}\text { Umidade da } \\
\text { madeira (\%) }\end{array}$ & $\begin{array}{c}\text { Ts } \\
\left({ }^{\circ} \mathbf{C}\right)\end{array}$ & $\begin{array}{c}\text { Tu } \\
\left({ }^{\circ} \mathbf{C}\right)\end{array}$ & $\begin{array}{c}\text { UR } \\
(\mathbf{\%})\end{array}$ & $\begin{array}{c}\text { UE } \\
(\mathbf{\%})\end{array}$ & $\begin{array}{c}\text { Potencial } \\
\text { de secagem }\end{array}$ \\
\hline aquecimento & 40,0 & 39,0 & 94 & 21,6 & - \\
\hline até 40 & 40,0 & 39,0 & 94 & 21,6 & - \\
\hline $\mathbf{4 0}$ & 40,0 & 38,5 & 91 & 19,8 & 2,02 \\
\hline $\mathbf{3 5}$ & 40,0 & 37,5 & 85 & 17,0 & 2,06 \\
\hline $\mathbf{3 0}$ & 40,0 & 36,5 & 80 & 15,1 & 1,99 \\
\hline $\mathbf{2 8}$ & 42,0 & 38,0 & $\mathbf{7 7}$ & 14,0 & 2,00 \\
\hline $\mathbf{2 6}$ & 45,0 & 40,0 & 73 & 12,8 & 2,03 \\
\hline $\mathbf{2 4}$ & 48,0 & 42,5 & 71 & 11,9 & 2,02 \\
\hline $\mathbf{2 2}$ & 51,0 & 44,5 & 67 & 11,0 & 2,00 \\
\hline $\mathbf{2 0}$ & 54,0 & 46,5 & 64 & 10,0 & 2,00 \\
\hline $\mathbf{1 8}$ & 57,0 & 48,0 & 58 & 8,8 & 2,05 \\
\hline $\mathbf{1 6}$ & 60,0 & 49,5 & 55 & 8,1 & 1,98 \\
\hline $\mathbf{1 4}$ & 60,0 & 47,0 & 47 & 6,9 & 2,03 \\
\hline uniformização & 60,0 & 53,0 & 67 & 10,0 & - \\
\hline condicionamento & 60,0 & 57,5 & 87 & 16,0 & - \\
\hline
\end{tabular}

Tabela 32. Programa de secagem empregado para a madeira de Peroba-Mica.

\begin{tabular}{cccccc}
\hline $\begin{array}{c}\text { Umidade da } \\
\text { madeira (\%) }\end{array}$ & $\begin{array}{c}\text { Ts } \\
\left({ }^{\circ} \mathbf{C}\right)\end{array}$ & $\begin{array}{c}\text { Tu } \\
\left({ }^{\circ} \mathbf{C}\right)\end{array}$ & $\begin{array}{c}\text { UR } \\
(\mathbf{\%})\end{array}$ & $\begin{array}{c}\text { UE } \\
(\mathbf{\%})\end{array}$ & $\begin{array}{c}\text { Potencial } \\
\text { de secagem }\end{array}$ \\
\hline aquecimento & 40,0 & 39,0 & 94 & 21,6 & - \\
\hline até 40 & 40,0 & 39,0 & 94 & 21,6 & - \\
\hline $\mathbf{4 0}$ & 40,0 & 38,0 & 88 & 18,3 & 2,19 \\
\hline $\mathbf{3 5}$ & 40,0 & 37,0 & 83 & 16,2 & 2,16 \\
\hline $\mathbf{3 0}$ & 40,0 & 35,5 & 74 & 13,3 & 2,26 \\
\hline $\mathbf{2 8}$ & 43,0 & 38,0 & 73 & 12,7 & 2,20 \\
\hline $\mathbf{2 6}$ & 46,0 & 40,0 & 69 & 11,6 & 2,24 \\
\hline $\mathbf{2 4}$ & 50,0 & 43,0 & 65 & 10,5 & 2,29 \\
\hline $\mathbf{2 2}$ & 54,0 & 46,0 & 62 & 9,6 & 2,29 \\
\hline $\mathbf{2 0}$ & 58,0 & 49,0 & 59 & 8,8 & 2,27 \\
\hline $\mathbf{1 8}$ & 62,0 & 52,0 & 56 & 8,0 & 2,25 \\
\hline $\mathbf{1 6}$ & 66,0 & 53,0 & 51 & 7,1 & 2,25 \\
\hline $\mathbf{1 4}$ & 70,0 & 54,0 & 45 & 6,1 & 2,30 \\
\hline uniformização & 70,0 & 62,5 & 70 & 10,0 & - \\
\hline condicionamento & 70,0 & 67,5 & 88 & 16,0 & - \\
\hline
\end{tabular}

Nas Tabelas 29 a 32:

$$
\begin{array}{ll}
\mathrm{Ts}=\text { Temperatura de bulbo seco } & \mathrm{UR}=\text { Umidade relativa do ar } \\
\mathrm{Tu}=\text { Temperatura de bulbo úmido } & \mathrm{UE}=\text { Umidade de equilíbrio }
\end{array}
$$

